NBER WORKING PAPER SERIES

\title{
SLAVERY AND THE INTERGENERATIONAL TRANSMISSION OF HUMAN CAPITAL
}

\author{
Bruce Sacerdote \\ Working Paper 9227 \\ http://www.nber.org/papers/w9227 \\ NATIONAL BUREAU OF ECONOMIC RESEARCH \\ 1050 Massachusetts Avenue \\ Cambridge, MA 02138 \\ September 2002
}

I thank the National Science Foundation for generous support and I thank Amitabh Chandra, Claudia Goldin and seminar participants at the NBER Summer Institute 2002 meeting for helpful comments. The views expressed herein are those of the author and not necessarily those of the National Bureau of Economic Research.

(C) 2002 by Bruce Sacerdote. All rights reserved. Short sections of text, not to exceed two paragraphs, may be quoted without explicit permission provided that full credit, including ${ }^{C}$ notice, is given to the source. 
Slavery and the Intergenerational Transmission of Human Capital

Bruce Sacerdote

NBER Working Paper No. 9227

September 2002

JEL No. J0, N0, I2

\begin{abstract}
$\underline{\text { ABSTRACT }}$
How much do sins visited upon one generation harm that generation's future sons, daughters, grandsons and granddaughters? I study this question by comparing outcomes for former slaves and their children and grandchildren to outcomes for free blacks (pre-1865), and their children and grandchildren. The outcome measures include literacy, whether a child attends school, whether a child lives in a female headed household, and two measures of adult occupation. Using a variety of different comparisons, (e.g. within versus across regions) I find that it took roughly two generations for the descendants of slaves to "catch up" to the descendants of free black men and women. This finding is consistent with modern estimates and interpretations of father-son correlations in income and socioeconomic status. The data used are from the 1880 and 19201 percent (IPUMS) samples, a 100 percent sample of the 1880 Census and a smaller data set in which I link families in the 1920 IPUMS back to the father's family in a 100\% sample of the 1880 Census. These latter data sets are derived from an electronic version of the 1880 Census recently compiled and released by the Mormon Church with assistance from the Minnesota Population Center.
\end{abstract}

\author{
Bruce Sacerdote \\ Dartmouth College \\ 6106 Rockefeller \\ Hanover, NH 03755 \\ and NBER \\ bruce.sacerdote@dartmouth.edu
}


"In America, anybody can become somebody."

Jesse Owens, Four time Olympic Gold Medallist, Medal of Freedom holder, Grandson of Slaves

\section{Introduction}

In 1967 Damon Keith was appointed to the U.S. District Court in the Eastern District of Michigan. In 1977 President Carter elevated Judge Keith to the U.S. Court of Appeals, $6^{\text {th }}$ Circuit, where he still works today. Judge Keith is remarkable in part for his decisions promoting racial integration in Detroit schools and in part for the fact that he is the grandson of slaves. ${ }^{1}$

Is a family's journey from slavery to professional and economic success in two generations a rare event? More broadly, after institutional or political barriers are lifted, how many generations are needed for outcomes for previously separated groups of people to converge? How long before the less and more advantaged groups converge on measures of income, health and education?

The rich existing literature on social mobility and income mobility would suggest that such convergence may take place rather rapidly. Many authors find that within OECD countries, the elasticity of son's earnings with respect to father's earnings is within the range of .3 to .5. (This range spans estimates by Altonji and Dunn [1991], Solon [1992], Zimmerman [1992], Mulligan [1997], and Bjorkland and Jantti [1997]. Solon [1999] is a detailed summary of this literature.) If income transmission follows a simple first order autoregressive (AR1) process, then the elasticity of a grandson's income with respect to his grandfather's income could be as little as $.3^{\wedge} 2$ or $.09 .^{2}$

Convergence of wealth between two previously separated groups may be similarly rapid. Charles and Hurst [2001] find parent-child wealth correlations in the range off .23-.5 which suggests that childgrandparent wealth correlations could be between .04 and .25 .

This simple math implies a great deal of income and wealth mobility within two generations. Grandchildren are quite likely to fall into a different income, wealth, or education quintile than their

\footnotetext{
${ }^{1}$ There are of course many successful African-americans alive today who can trace their roots back to slavery. The most famous may be L. Douglas Wilder, the former governor of Virginia who actually became governor of the state in which his grandparents were enslaved.

${ }^{2}$ By AR1, I mean autoregressive with the current generation's outcomes dependent on only one lagged value of the data. In other words, if a child's income depends upon the income of her parent's but not income from previous generations, then we can simply square the parent-child coefficient to get the parent-grandchild relationship. Recent work by Mazumder [2001] finds parent-child income correlations that are even higher than those of Zimmerman or Solon. However, the basic implication of very high mobility within two generations remains.
} 
grandparents. And hence, groups of people that start with very different levels of physical and human capital could end up with similar distributions of income, education, physical and human capital two generations down the road. Whether or not such convergence actually takes place will depend in part on the degree to which institutional and social barriers that separate the two groups are lifted.

This paper tests the theory of convergence (or at least high mobility) within two generations by comparing outcomes for former U.S. slaves, their children and their grandchildren to outcomes for free blacks born before 1865 and their children and grandchildren. The outcomes examined include literacy, whether or not children ages 7-18 are in school, months spent in school, whether children live in a female headed household and two measures of occupation and occupational socioeconomic status. (I examine median income by occupation and I use a dummy for manual versus non-manual occupation.)

The paper uses Census data from 1880 and 1920. I group people into three generations and examine outcomes for householders born before 1865 and their children and grandchildren. ${ }^{3}$ I also present summary statistics by birth cohort. For one set of results, I have linked fathers in the 1920 IPUMS sample back to their families in 1880. This linked data set allows me to measure the coefficient transmission of socioeconomic status from grandfathers to grandsons (holding father's socioeconomic status constant).

I find that in 1880 there is a huge literacy gap between former slaves and free blacks, and that this gap narrows considerably over the next two generations. Similarly, the children of former slaves are less likely to be enrolled in school than the children of blacks born free, but this gap disappears when we examine the grandchildren of blacks born into slavery and the grandchildren of blacks born free. Former slaves do work in occupations with lower median income than blacks born free. However, once I control for current region, this gap is small and relatively constant between 1880 and 1920 .

I use data on whites to test whether the "effect of slavery" that I measure is merely the effect of being born (or having an ancestor) in the South. I find that the slavery effect and its disappearance over time is a separate phenomenon from the effect of being born in the South.

Relation to the literatures on slavery, intergenerational transmission, black-white wage gaps, and NorthSouth wage gaps

\footnotetext{
${ }^{3}$ Throughout the paper, I use the word householder to refer to the head of household and his or her spouse if any. I use the term "free blacks" to refer to blacks who were free prior to 1865. I use year and place of birth to classify blacks as being born into slavery or not. The assumptions behind this classification are defended in the data section that follows.
} 
The paper's topic is related to at least four enormous literatures within economics and economic history. As discussed above, the hypothesis being tested is whether or not large gaps in income and human capital between two groups can be closed within two generations. This hypothesis is an implication from the literature on intergenerational transmission of income.

This logic regarding high mobility or convergence between groups within two generations has not been widely tested empirically, perhaps because there are not many longitudinal data sets that contain detailed income data on more than two generations of family members.

The current paper closely follows Margo [1990] in terms of the data used and the outcomes considered. Margo uses Census data to examine black-white differences in literacy, school attendance, years of schooling, occupation and wages and provides a detailed discussion of these Census variables. Because I am only using the 1880 and 1920 Censuses, I can not look at years of schooling or wages.

The literature on the $20^{\text {th }}$ Century black-white gap (eg Smith and Welch [1979], Welch [1989] and Margo[1990]) has found strong convergence of wages between the 1940s and 1970s, which is consistent with my simple interpretation of parent-child income transmission coefficients. The more recent additions to this literature including Chandra [2001], Johnson and Neal [1996], and Heckman, Lyons and Todd [2000] do not find a narrowing of the black-white wage gap during the 1980-1990 period.

While this contrasts with my findings regarding nearly complete convergence within blacks during 1865-1920, it is certainly possible to reconcile the two results. It is likely that institutional or cultural barriers between two groups of blacks were lower than barriers between blacks and whites. This fact could explain the rapid intra-black convergence that I find and the slower black-white convergence that others find. The persistence of black-white differences could be explained if a new set of discriminatory institutions rose up after emancipation (as in Wright [1986]), and these institutions were not dismantled until the 1960s and 1970s as argued by Donohue and Heckman [1991], Darity, Dietrich and Guilkey [2001] and Almond, Chay and Greenstone [2001]. It is of course more difficult to understand why the black-white convergence process would get under way and then stop.

Margo [2001, 1995] and Wright [1986] show that controlling for occupation, black-white wage gaps in the post-Bellum South were small. This suggests the importance of understanding the degree to 
which freed slaves and their descendants sorted into lower paying occupations (relative to free blacks and their descendants or relative to whites) which is one of the questions I examine. ${ }^{4}$

Atack [1994] concludes that freed slaves in the South experienced at least a 34 percent gain in income from emancipation, if one considers the value of increased leisure time. This is Atack's compilation of estimates provided by Ransom and Sutch [1977] and Fogel and Engerman [1974]. If this estimate is correct, then such a large jump in income would mechanically imply some convergence in income levels between slaves and free blacks as a result of emancipation. I address the period after emancipation and ask whether such convergence continued.

Fogel and Engerman [1974] show that many slaves were skilled craftsmen with high levels of human capital. It is likely that such human capital owned by freed slaves benefited themselves and their descendants and would have facilitated convergence in socioeconomic status between descendants of slaves and descendants of free blacks. ${ }^{5}$

Does my claim of within black convergence, based on Census data, agree with the experience of intellectuals who lived during the late nineteenth and early twentieth century? This is not an easy question to answer since most writers of the day focussed on black-white differences or absolute measures of black poverty and lack of education, without regard to differences in ancestry. W.E.B. DuBois [1899] made a detailed study of black families in Philadelphia and in his text he makes several references to the idea that opportunities for jobs and education were similar for northern black families and recently arrived black emigrants from the South.

However, DuBois is very clear in his belief that slavery had a deleterious effect on the stability of the black family, introducing what he called tendencies towards loose cohabitation, marriage at too young an age, and family dissolution. My evidence is consistent with DuBois' claim in that I do find a large effect of slavery on the probability that a child lives in a female headed household. And the size of this effect only declines moderately from 1880 to 1920.

The writings of Booker T. Washington indicate a strong willingness to learn to read on the part of freed slaves and their children. This supports the claim that the descendants of freedmen had the potential

\footnotetext{
${ }^{4}$ The existing work on post-Civil War wages and income is far more detailed and comprehensive than what I can provide using Census data. My interest is really in following families over time using the crude outcome measures in the Census.

${ }^{5}$ I am heavily indebted to the work of Fogel and Engerman [1976] and Atack [1994] who provide a wealth of detail on the occupations, living conditions, human capital, and geographic location of slaves and free blacks.
} 
to converge towards the literacy and schooling levels of descendants of free blacks. At the same time, Washington's personal childhood stories indicate that his freed family's extreme poverty was an enormous obstacle to his learning to read and his ability to attend the Hampton Normal and Agricultural Institute in Virginia. Overall, the primary source material written by black intellectuals and by ordinary black citizens during the post-Bellum period expresses hope that freed slaves could improve their economic situation, but also acknowledges large obstacles along the way.

The remainder of the paper is structured as follows: Section II outlines the empirical approach and three separate estimators of the differences in outcomes between former slaves and their progeny and free blacks and their progeny. Section III discusses the data and how I classify people as being born slaves versus born free and Section IV presents the empirical results. Section V explains the merged sample of families in both the 1880 and 1920 Censuses and presents results for this sample. Section VI concludes.

\section{Empirical Approach}

All of the estimates of the difference in outcomes between former slaves and free blacks (and their children and grandchildren) are presented either as a difference in means or as a coefficient from an ordinary least squares regression. In the simplest analysis, one could estimate the difference in outcomes between former slaves and free blacks (and their progeny) as the raw difference between the two groups, without controlling for a given family's current location. For example, I estimate the difference in literacy between the groups as $\beta 1$ in the following regression:

(1) literacy $=\alpha+\beta 1 *$ former slave $+\gamma \mathbf{X}$.

Here $\mathbf{X}$ is a vector of controls including a dummy for male, the number of children in the household, and birth year dummies. When I measure the effect of slavery on the first generation born after emancipation, the right hand side variable of interest becomes whether or not a person's mother was born into slavery. And for the second generation after emancipation, the dummy is for whether or not the person's mother's mother (maternal grandmother) was born a slave. ${ }^{6}$

In this simple analysis, $\beta 1$ is obviously picking up more than just the negative impacts of slavery itself. Most former slaves and their families continued to live in the South and hence were affected by schooling conditions, labor market conditions and social interactions that were different than those

\footnotetext{
${ }^{6}$ Most of the dependent variables are binary and I report coefficients from linear probability models. The marginal effects from probits are not reported here, but are extremely similar.
} 
experienced by blacks outside the South. ${ }^{7} \quad$ For this reason I also attempt to identify the effect of former slavery status on own and children's outcomes by using families that move-both families of former slaves that move out of the South and families of free blacks that move into the South. I do this in two ways: First, I run equation (1) for the subsample of people currently outside (inside) the South. Second, I run equation (1) for the whole sample and include region dummies.

For the purposes of this paper, my dummy for South is actually a dummy for former slave state and hence includes Missouri as well as Delaware, West Virginia, Virginia, Maryland, North Carolina, South Carolina, Georgia, Florida, Alabama, Mississippi, Tennessee, Kentucky, Louisiana, Arkansas, and Texas. ${ }^{8}$ I am not attempting to use any distinctions between the Old and New South or border versus nonborder states or Confederate versus not for identification.

The above approach estimates the effect of slavery as the difference in outcomes between black families that move out of the South and black families that were already outside of the South. This estimate assumes that families that leave the South are similar to families that do not move. If the families that move have unobservably higher SES or human capital (as argued by Margo [1986 and 1990]), then my estimate will understate the effects of slavery and will implicitly overstate the speed of convergence. ${ }^{9}$

My third estimator of the difference in outcomes for former slaves (and their families) and free blacks (and their families) uses outcomes for whites to estimate the effects of being born in the South separately from the effects of slavery. For the first generation following emancipation, I run the following regression for black and white families:

(2) literacy $=\alpha+\beta 0 *$ black $+\beta 2 *$ mother born in slave state $+\beta 1 *$ black and mother born in slave state + dummies for current region $+\gamma \mathbf{X}$.

I then interpret $\beta 1$ as the effect on child's literacy from having a mother born into slavery. $\beta 1$ is the interaction effect of being black and having a mother born in the South, over and above the main effects of being black, having a mother born in the South, and current region. The principal objection to this

\footnotetext{
${ }^{7}$ Margo [1986, 1990] and Donohue, Heckman, and Todd [1995] are among the many papers document the poor state of black public schools during this time period.

${ }^{8}$ West Virginia was not a separate state until 1863, but I list it here for clarity as to which geographic areas I am labeling slave states.

${ }^{9}$ Clearly families that move are different than ones that stay and so I offer the various estimates of the effect of slavery not as perfect estimates, but rather as the best estimates that I can devise.
} 
approach is that I attribute all of the interaction effects of being born black and in the South to slavery, when in fact there is good reason to believe that post-slavery institutions in the South were also differentially worse for blacks.

After presenting the above results, I test whether or not intergenerational transmission of socioeconomic status (SES) depends solely on parent's SES or also depends on grandparent's SES.

To test this I run regressions of the following form ${ }^{10}$ :

(3) son's income score $=\alpha+\beta 5^{*}$ father's income score $+\beta 6^{*}$ grandfather's income score + dummies for current region $+\gamma \mathbf{X}$.

I interpret the coefficient $\beta 6$ as a measure of the degree to which grandparent's SES matters over and above the transmission through parent's SES. This test must be taken with a pound of salt since measurement error in income scores could yield a significant coefficient on grandfather's income score even if the effect works strictly through father's income score. I also test whether the elasticity of grandson's SES with respect to grandfather's SES simply the square of the father-son elasticity.

${ }^{10}$ The income score in equation (3) is described in the next section. 


\section{Data Description}

The data come from the 1880 and 1920 U.S. Censuses. (I have also run but in the interest of space, do not report results from the 1870 and 1900 Censuses.) The first set of results use the 1 percent IPUMS (Integrated Public Use Micro Samples) created by the Minnesota Population Center at the University of Minnesota. These data sets provide basic demographic variables for a large number of households and the individuals within those households.

I also have some data items from a 100 percent sample of the 1880 Census. These data were compiled by the Church of Jesus Christ of Latter Day Saints (The Mormon Church) for genealogical research. The Minnesota Population Center assisted the Mormon Church in cleaning and preparing the data for a release on a set of 35 CDs. This project took 20 years and thousands of volunteers to complete. The main disadvantage of the 100 percent sample is that the Mormons pulled a limited subset of variables including names, places of birth, age, race, and occupation. I present results based on a 100 percent sample of black families living in New England and in the New York City area, which consists of New York City plus Westchester, Suffolk, and Nassau Counties.

Table I contains descriptive statistics for both the 1880 and 19201 percent samples. The 1880 sample contains 12,342 black children and 55,570 white children. In the 1880 sample I drop children who are older than 15 because they were born before the Civil War ended. I also drop children who are younger than 7 because they have missing values for both the schooling measure and the literacy measure. I drop any heads of household or their spouses who were born after 1865. (There were very few such cases.)

Within the 1880 sample, 97 percent of black children had a mother born in a slave state and 93 percent of black children live in a slave state now. On average, the black children come from a family of four children and the white children come from a family of 3.7 children.

Thirty-five percent of the black children and 88 percent of the white children are reported as being literate. Census enumerators asked separately about ability to read and ability to write for each individual in the household. The questions are only asked for persons age 10 or older. I coded the literacy variable as a dummy variable which equals 1 if the person is able to read and write. 
A separate census question asked whether or not each person was enrolled in school any time during the previous year. I created an "in-school" dummy for all children who were aged 7-18. The dummy equals 1 if the child was enrolled in school in the past year and 0 if the child was not enrolled. Table I shows that 32 percent of black children and 73 percent of white children (ages 7-18) in the 1880 sample were reported as enrolled.

One criticism of this variable is that it does not capture the number of days of schooling during the year, but rather asks for any school attendance at all. To mitigate this problem, I also report one table of results from the 1900 Census, because the 1900 Census collected the number of months that each child was in school during the past year.

The Censuses also asked for the occupation of each person in the household. This was written down as a text field by the enumerator. Children who do not have an occupation are frequently listed as being "At Home." I use the occupation variable in several ways. First IPUMS researchers have linked each occupation to the median occupational income from the 1950 census. ${ }^{11}$ This number is reported as annual median income by occupation in hundreds of 1950 dollars. Table I shows that the black male heads of household in the 1880 sample have an occupational income score of 15.24 versus 19.88 for the white male heads of household. These figures exclude men with occupations that have a score of 0 (for example, "retired") and men with no occupation listed.

The occupational score is obviously a highly imperfect measure of income. The biggest problem is the fact that relative incomes among occupations undoubtedly shifted between 1880 and 1950, when median incomes are calculated. Furthermore, it is likely that some 1880 occupations are misclassified because the nature or name of the occupation changed greatly during 1880-1950. The one positive thing to be said for occupation scores is that median incomes by occupation may be a less noisy measure of permanent income than a single year of self reported income. Despite the limitations of the occupational income score, papers such as Angrist [2001] and Darity, Dietrich, and Guilkey [2001] do use the measure because it is available for long periods of time and is not subject to the same measurement error as self reports of income.

While the occupation score is probably a bad measure of actual income, it may be a reasonable index of "socioeconomic status." Occupations that paid a lot in 1950 were probably also high paying, high human capital, desirable jobs in 1880. Appendix Table III shows the 1880 occupations and income

\footnotetext{
${ }^{11}$ Details are available at www.ipums.org. The 1880 Census did not collect individual income.
} 
scores for blacks heads of household who were born free. These data are from the 100 percent sample of black families in New England and the New York metropolitan area. Physicians have the highest score in the table (at 80). Craftsmen have scores that range from 24-29 (not shown) and unskilled laborers have income scores of 9. One glaring problem is that preachers and clergy receive a relatively low occupational income score of 24 despite the fact that these preachers were among the most educated and influential members of the black community during the time period in question. Figures VIII and IX show the full distribution of scores for male household heads by race in 1880 and 1920 .

In addition to using the occupational income score as the dependent variable, I also use reported occupation to classify men as having manual or non-manual jobs. This classification has some intuitive appeal and classification mistakes are less likely than with the occupational income score. However, there is only a modest amount of variation in the manual job dummy. Table I shows that 84 percent of white male heads of household were manual workers and the equivalent figure for blacks is 96 percent.

Panel B of Table I gives the means for the 1920 sample. By 1920, 83 percent of the black children are literate and 99 percent of white children are literate. Sixty-seven percent of black children are in school versus 81 percent for whites. The average child age is much higher for the 1920 sample because I include children in the household who are age 35 or younger. (In the 1880 sample, I excluded any child born before 1865.) The occupational income scores for the male householders in 1920 are modestly higher than in 1880, and the percent who are manual workers is modestly lower.

\section{Classification of Slavery versus Non-Slavery Status for Blacks}

I classify blacks as being born into slavery if they are born in a slave state before 1865 . While this appears to be a bold assumption, it turns out to be a reasonable approximation to the truth. Fogel and Engerman estimate that in 1860, 94 percent of blacks in the South were slaves. This approximation can be confirmed by examining the 1860 Census IPUMS data by state, by race (not shown in the interest of space). These counts include only the free population in a 1 percent sample and show only 2,485 free blacks in the 16 slave states. In 1880, the 1 percent sample contains 51,618 blacks living in the former slave states. Thus the ratio of free blacks in 1860 to total blacks in 1880 is roughly $248,500 / 5,161,800$ or 4.8\%. Fogel and Engerman estimate that the slave population in 1860 was roughly 4 million, which implies that the ratio of free blacks to total in the South in 1860 was roughly 5.8 percent. 
In truth many of the 248,500 free blacks in the South in 1860 were born as slaves, but were manumitted. ${ }^{12}$ So 94 percent is an underestimate of the percentage of Southern blacks who were born into slavery. Olwell [1996] documents that many free blacks in the South purchased their own freedom using extra income earned working on their "own time." We know from Phillips [1997] and Gould [1998] that many of the free blacks in the South lived in Baltimore, New Orleans and Charleston and the other major cities. I could further improve my approximation by dropping blacks in these cities.

If free blacks in the South were primarily manumitted slaves, who were the free blacks in the North? Work by McManus [1966], Hodges [1997], and other historians suggests that many of the blacks in the ante-bellum North were the descendants of colonial era slaves. My examination of the 100 percent sample of the 1880 Census is consistent with this claim. In Appendix Table II, I list the birthplace of the mother of the female householder (ie the 1880 children's mother's mother) for free black households in New York and New England. Fully 36 percent of the mothers in my sample had mothers born in New York and 16 percent had mothers born in Connecticut. This does not demonstrate that free black families have northern roots that extend back to the American Revolution, but it does show that the vast majority are not recent migrants to the region. This fact is important for interpretation of my results, because in essence I am comparing the descendants of slaves from one era to the descendants of slaves from a more recent era.

Appendix Table III gives a breakdown of the occupations held by male heads of household among free black families in New England and the New York metro area in 1880. These are from the 100 percent sample. Not surprisingly, the most common occupations include laborers, farm laborers, and farmers. "Waiter" is the third most common occupation, but this is only because a large part the sample is from New York City.

Figures I through V present mean outcomes by race, place of birth, and by birth cohort. Figure I shows average literacy rates by 10 year birth cohort for slaves and their descendants and for free blacks and their descendants.

Unsurprisingly, there is a huge literacy gap between blacks born as slaves and blacks born free. Free blacks born in 1850-1860 have about a 65 percent literacy rate as measured in the 1880 Census. Blacks born into slavery during 1850-1860 have about a 22 percent literacy rate. Several economic

\footnotetext{
${ }^{12}$ Fogel and Engerman use census data to estimate numbers of manumissions. Olwell [1996] contains a wealth of detail regarding the circumstances surrounding individual manumissions.
} 
historians have represented to me that the 22 percent literacy rate for former slaves appears to be vastly overstated given that slaves had very limited opportunities for education under the plantation system. It is certainly conceivable that some former slaves learned to read as adults after emancipation. Indeed, the literacy rate among the 1850-1860 birth cohort of former slaves as measured in the 1870 Census is a modestly lower 17 percent. This is consistent with the idea of blacks learning to read after Emancipation. But another likely explanation is that respondents to the 1880 Census had some tendency to overstate their own degree of literacy.

Looking at the first generation born after slavery, children of former slaves and children of free blacks born pre-1865, both have a huge gain in literacy. There is a fair amount of upward convergence in which the children of slaves begin to achieve literacy rates closer to rates for children of free blacks. By the third generation, the grandchildren of free blacks have literacy rates approaching 100 percent and the grandchildren of free blacks have further narrowed the gap.

Figure II shows literacy rates by birth cohort, race, and place of birth (South versus non-South.) There is a negative effect on literacy from being black, and a negative effect from being born in the South. But the interaction effect of being black and in the South is much bigger than the black or South effects alone. By the 1895 birth cohort (1890-1900), all whites and blacks born outside the South have literacy rates approaching 100 percent. Blacks born in the South during 1890-1900 have about an 82 percent literacy rate.

Figure III shows the percent of children who are living in a female headed household, by race, birth cohort, and slave state parentage. I define a female headed household as one in which a woman is the head of household as listed by the Census enumerator. Invariably, such households do not contain a person listed as that woman's spouse. ${ }^{13}$ The first group of data points are for children born during 18701880 in the 1880 Census and the data are stratified by race and mother's birth in a slave state. The other two cohorts are the 0-10 year old children in the 1900 and 1920 Censuses. Here I stratify by race and maternal grandmother's birth in a slave state. I limit these households to ones with the mother born between 1865 and 1885 which implies that the mother's mother was likely born before 1865 .

Black children are uniformly more likely to live in a female headed household than white children. In 1880, black children of free mothers are about 5 percent less likely to live in a female headed

\footnotetext{
${ }^{13}$ There remains the possibility that the spouse was living in a nearby dwelling or had left to seek work to support the family. Female headed households in 1880 may be very different than female headed households in 1980 and I discuss this in the results section.
} 
household than children of slaves. This effect does not diminish with the data from 1900 and 1920 Censuses. Grandchildren of slaves are more likely to live in a female headed household than grandchildren of free blacks.

Figure IV shows occupational income scores for free blacks and their progeny and former slaves and their progeny. There appears to be roughly a 3-5 point gap between the two groups that does not close over time. However, once I control for current region (as in the next section) this gap is not statistically significant, even for the first generation. ${ }^{14}$

Figure V shows occupational income scores by birth cohort, race, and born in South (0-1). The rank ordering from highest to lowest is non-Southern born whites, Southern born whites, non-Southern blacks, and Southern blacks. This pattern appears to persist across the sample period and does not show much convergence or divergence. (Recall that the income score does not allow incomes to vary within an occupation over time.)

Figures VI and VII look at coefficients of transmission of literacy and occupational income score. Figure VI shows the OLS coefficient of child literacy on mother's literacy by birth cohort. This coefficient falls steadily over birth cohorts. This happens during a period of greatly increasing literacy. However, falling transmission coefficients are not automatically (algebraically) implied by increasing literacy rates or rates that asymptote to 100 percent. Interestingly, the rate of transmission of literacy is higher for blacks than whites for every single birth cohort.

Figure VII calculates transmission coefficients for occupational income score by birth cohort. The transmission coefficients in Figure $\mathrm{V}$ appear to be much noisier than those for literacy and no obvious time trend is apparent.

\section{Results}

Results are presented in Tables II through XIV. Tables II through V estimate the effects of slavery on outcomes by comparing free blacks and their descendants to former slaves and their descendants. Tables VI through $\mathrm{X}$ use data on blacks and whites and estimate the effect of slavery as the interaction between being black and being born in a slave state. Tables XI through XIV estimate transmission coefficients of literacy and occupational income score using data on grandparents, parents, and children.

\footnotetext{
${ }^{14}$ Controlling for current region, there is never a gap between free blacks and slaves in terms of occupational income score. Hence it doesn't make much sense to think about convergence along this measure.
} 


\section{Effects on Literacy}

Table II examines the difference in literacy rates between former slaves and free blacks and the descendants of each group. The table is organized as follows: Column (1) describes the sample (e.g. men versus women). Column (2) states which controls are in the regression. Columns (3)-(5) are the OLS coefficient on the slave status dummy and the means, standard deviations, and sample sizes for the dependent variable categorized by former slave or free. Column (6) provides a comparison by estimating the analogous OLS coefficient (on birth in a slave state) for whites.

The first panel is for householders in the $18801 \%$ sample. $^{15}$ The sample is limited to householders born before 1865. Rows (1) and (2) show the raw (uncontrolled) effect of slavery status on literacy for men and women. Slave status is associated with roughly a 47 percent decrease in the probability of being literate for both men and women. For women (men) this effect drops to -26 percent (-21 percent) when I include dummies for current region and birth year [results shown in rows (3) and (4) ]. Almost all of this decrease in the coefficient is attributable to the inclusion of the region dummies. By including current region dummies, the coefficient on slave status is identified from blacks that move (either into the South or out of the South) between birth and $1880 .{ }^{16}$

The whole sample in the first panel of Table II only contains 542 free blacks. This is basically an issue of precision of the estimates and the standard errors in the tables reflect this small sample.

The next panel of Table II shows analogous regressions for the children of these same householders in 1880. The children here are ages 10-15 ; I limit the sample to children born post-1865 and literacy is only measured for persons 10 or older. Without controls, the free vs. former slave literacy gap is even larger for the children in 1880 than for the householders. For the children, the uncontrolled effect on the slavery status dummy is 55 percent and the effect controlling for current region is 10 percent. Rows (3) and (4) show results when the sample is limited to households currently outside or inside the South.

The third panel of Table II takes another look at literacy in the first generation after slavery, but this time using the 1920 IPUMS sample. The sample consists of black householders ages 35-55. These adults are too young to have been born into slavery, but old enough that their parents most likely were

\footnotetext{
${ }^{15}$ I use the term "householder" to refer to the head of household and his or her spouse if any.

${ }^{16}$ Unsurprisingly the effect of birth in a slave state for whites is much smaller. The raw effect is only 16 percent and the effect falls to 8 percent when I include regional dummies.
} 
born before $1865 .{ }^{17}$ In this sample, the effect of mother's former slavery status on literacy is much smaller than for the children in the 1880 sample. The uncontrolled effect of mother's slavery status on own literacy is -28 percent. When I add dummies for current region, the effect falls to -10 percent, and when I limit the sample to blacks currently outside the South, the effect falls to -6 percent.

Given the figures in Table II, one could make the case that much of the effect of slavery status on literacy disappears after one generation, if we control for current region. The importance of the current region dummies could imply that families that move are inherently different from families that stay in the South. Or it may imply that the families that move benefit from the different labor market and schooling conditions outside the South. This second interpretation is needed to make the case that controlling for region yields the best estimates of the effect of slavery status.

The final panel of Table II examines literacy for the second generation after slavery, using the children of the 1920 householders. The sample is constructed such that these are children with a mother is age 35-55, and I assume (as above) that the mother's mother was born prior to 1865 . I examine the effect of grandmother's slave status on grandchild's literacy. The raw effect of grandmother's slavery status on the probability of being literate is -16 percent. When I control for current region, or look only at children outside the South, the effect falls to -3 percent and 0 percent. Therefore, controlling for current region, the effect of slavery status on literacy disappears completely by the second generation after emancipation. One of the disadvantages of the literacy measure is that literacy rates are fast approaching 100 percent, which is why I consider additional outcomes.

\section{Effects on Schooling}

In addition to effects of slavery status on literacy, I am also interested in examining effects on schooling. Unfortunately during this time period the Census did not collect years of schooling. But we can examine whether or not children in the household were enrolled in school during the past year. As mentioned above, I create a binary variable for enrollment and measure this for all children aged 7-18. Table III examines the effect of mother's slave status on child's school enrollment. The sample in the first panel consists of black children ages 7-15 in 1880 households, where the upper age limit of 15 is to limit the sample to children born after the Civil War.

\footnotetext{
${ }^{17}$ This is a big assumption, but probably an accurate one for the majority of householders. The youngest householders in the sample were born in 1885, and some of them might have been born to parents who were born after 1865, but this would be a small fraction of my total sample.
} 
Without controls (ie the difference in means), children of former slaves are 36 percent less likely to be enrolled in school. Controlling for current region, children of former slaves are 8 percent less likely to be enrolled in school.

The second panel uses the 1920 data to look at the effect of grandmother's (mother's mother's) slavery status on grandchild's probability of being enrolled. Grandchildren of slaves are 9 percent less likely to be enrolled than grandchildren of free blacks. But, controlling for current region, this effect is not significantly different from zero.

Table IIIa uses data from the 1900 Census to examine the effect of grandmother's slavery status on the child's number of months spent in school. On average, grandchildren of slaves spent 4 months in school, versus 7 months for the grandchildren of free blacks. However, controlling for current region reduces this gap to a statistically insignificant .3 months.

\section{Effects on Female Headed Household Status}

Many social scientists (including Frederic Bancroft and W.E.B.DuBois) have argued that slavery caused a breakdown of the traditional family structure among blacks and that this problem persisted long after emancipation. I investigate this hypothesis in Table IV by comparing the prevalence of female headed households for children of free blacks and children of slaves. The first panel of Table IV is for the children ages 0-15 in the 18801 percent sample. ${ }^{18}$ My dependent variable is a dummy for whether or not the child was living in a female headed household at the time of the Census. The raw (uncontrolled) difference in the female headed household rate between the children of slaves and children of free blacks is 4.1 percent and is statistically significant. The means are 13.5 percent for the children of slaves and 9.4 percent for the children of free blacks. The effect of mother's slave status is quite large relative to the mean female headed household rate.

Controlling for region (the second row) actually increases the coefficient on the dummy for "mother born slave" to 8.9 percent. We can see from the final two rows in the panel that this large effect is from those few free black families that move back to the South; such families are very unlikely to be female headed households. Given how rare such movers are, I am inclined to use either the raw difference of 4.1 percent (the first row) or the difference among families outside the South of 6.8 percent as the best point estimate of the effect of mother's slavery on female headed household status.

\footnotetext{
${ }^{18}$ Figure III shows data for children $0-10$ because the figure is for 10 year birth cohorts.
} 
Additional estimates are shown in panel 2 of Table IV. I am able to look at female headed household status for children within the 100 percent sample of the 1880 Census. Here I show estimates for all black children in New England and all black children in New York City. Within New England there is no difference in female headed household status between children of free blacks and children of slaves. Within New York City there is a very large effect from mother's slave status.

The third panel of Table IV is for the children in the 19201 percent sample. These children are the grandchildren of former slaves and free blacks. This panel also shows large point estimates for the effect of grandmother's slavery status on the probability of a child's living in a female headed household. Grandchildren of slaves are 6.5 percent more likely to live in a female headed household than grandchildren of free blacks, though this difference is not statistically significant at conventional levels.

Unlike the results for literacy and school attendance, the effects of slavery on family structure appear to have persisted well into the twentieth century. This provides one possible channel through which slavery could have long lasting effects on successive generations of black Americans. Two caveats are worth mentioning. First, we know that in more modern data, female headed households are strongly associated with poverty, criminal victimization, low employment, and lower educational attainment. However, the female headed households of 1920 may have been less damaging, and the reason for the father's absence may have been very different then versus now. For example, the fathers may have been living elsewhere in order to secure work and income for the family.

Second, the prevalence of black female headed households in 1880 was much less than in 2000. While 13 percent of black children in 1880 were in female headed households, 42 percent of black children in 2000 lived in female headed households ${ }^{19}$. Thus the effects of slavery would have to be both severe and increasing over 150 years in order to explain a substantial fraction of the present day prevalence of black female headed households.

\section{Effects on Occupation}

Now I turn to the effect of slavery status on male household head's occupation, as measured by the occupational income score and a dummy for manual occupation. The first panel in Table V uses the 1880 1 percent sample and compares black heads of household born into slavery to those born free. Controlling

\footnotetext{
${ }^{19}$ Calculated from the 2000 Census STF2 using American FactFinder on www.census.gov.
} 
for current region, being born a slave lowers the occupational income score by only .13, though it makes heads 3 percent more likely to be manual workers. (The mean of "manual" for free blacks is 82 percent.)

The second panel of Table V computes the same coefficients, but for a portion of the 100 percent of the 1880 Census. Within both New England and New York, former slavery status is not associated with statistically different occupational income scores. Furthermore, there is no effect on manual worker status.

The third panel looks at the analogous effects for male heads of household in the 1920 sample. These are the children of former slaves and free (pre-1865) blacks. Controlling for region, the effect of father's mother's slave status on the occupational income score is a small and statistically insignificant.77. The effect of mother's slave status on likelihood of being a manual worker is 6 percent and is statistically significant at the 10 percent level.

Thus the estimated effect of slavery status on manual worker status is somewhat larger for the children of slaves (panel 3) than for the former slaves themselves. This is plausible and consistent with Margo's [1990] discussion of the transition of labor from the farm to the nonfarm sector. In 1880, nearly everyone was a manual worker, and slavery status had little effect on manual status. During the next 40

years, those workers with high levels of human capital were the most likely to exit the farm sector. If children of slaves received less education than children of free blacks (as shown in Tables II and III), then children of free blacks were differentially more likely to exit the agricultural sector.

\section{Effects on Home Ownership}

Ideally one would also look at wealth differences between the descendants of slaves and descendants of free blacks. The Census data do contain an indicator variable for homeownership. In 1920, 34 percent of the householders who are children of slaves own their own home. The comparable number for householders descended from free blacks is 32 percent. If we thought that home ownership was a measure of wealth, we might conclude (almost surely incorrectly) that slavery increased family wealth. However, we have no measure of the quality or value of the home and we do know that home ownership in 1920 is highly correlated with work in agriculture. Many of the black homeowners may be sharecroppers and might own as little as a shack, so the homeownership measure is not particularly informative about wealth. 
The above results use data on movers to separate the effects of slavery from the effects of growing up or living in the South. An alternative method for separating these two effects is to use whites to estimate the baseline effect from being born in the South (but not being born a slave). I estimate the baseline of effects of "born South" and black and the interaction effect of being both black and born in the South. I label this interaction effect the effect of slavery ${ }^{20}$

This analysis obviously relies on the assumption that the level effect of "born South" is identical for blacks and whites, and that one can attribute remaining differences in outcomes between blacks and whites to slavery. This is clearly an aggressive assumption. It is less clear whether this assumption is better or worse than the previous analyses which assumed that black movers and stayers in the non-South were similar except for slavery status.

Table VI presents mean outcomes for blacks and whites segmented by race and by birth in a former slave state. In Panel A, I show mean literacy by race and born in a slave state for female householders in 1880. All are born pre-1865. The slave state - free state difference in literacy rates for blacks is -46.3 percent while the same difference for whites is -15.7 . Therefore the "effect" of own slavery status on literacy is -30.6 percent.

Panel B measures this difference in difference for children in the 1880 Census. The table shows literacy rates by black versus white and mother born inside or outside of a slave state. The slavery effect is 30.0 percent, which is the same as the effect for the mother's in Panel A. This is consistent with the earlier comparisons which showed no decrease in the slavery effect on literacy for the 10-15 year olds in 1880 , i.e. one generation after slavery.

Panels C and D also look at literacy one generation after slavery, but this time using householders in 1920. By this time, the effect of mother's slavery has dropped to -24.6 percent for women and -12.7 percent for men. Panel E calculates the effect of grandmother's slavery status for children in the 1920 Census. Two generations after emancipation, the effect of grandmother's slavery status on the probability of being literate is -13.1 percent. Therefore, using the difference in difference estimator, the effect of slavery does not disappear within two generations, but the effect does greatly diminish in two generations.

\footnotetext{
${ }^{20}$ Before adding controls, I am just taking the black-white difference for people born in the South and subtracting off the blackwhite difference for people born outside of the South.
} 
Panels $\mathrm{F}$ and $\mathrm{G}$ use the in-school dummy as the dependent variable. In 1880, children of slaves are 12.5 percent less likely to be enrolled in school than children of free blacks, again differencing out the whites as a control. In 1920, grandchildren of slaves are 7.2 percent less likely to be enrolled in school than grandchildren of free blacks.

These difference in difference estimates show substantial convergence between the descendants of free blacks and slaves over two generations, at least for literacy and schooling status. Unlike the earlier movers versus stayers analysis, the estimates do not show complete convergence.

Tables VII through X perform the same analysis using OLS and add dummies for current region. In all columns, the outcome of interest is regressed on a dummy for born in a former slave state, a dummy for black, and the interaction of the two; the interaction is the coefficient of immediate interest.

Columns (1)-(4) in Table VII examine literacy for male and female householders in 1880. All of the people in the sample were born prior to emancipation. The interaction of being black and being born in slave state depresses the probability of being literate by roughly 30-33 percent. Interestingly, the coefficients change little when I control for current region.

Table VIII examines the effect of mother's slave status for children in the 1880 Census. Controlling for current region, having a mother who was born a slave decreases the probability of literacy by 29 percent and the probability of being enrolled in school by 12 percent. Table IX runs the literacy regression for male and female householders in the 1920 Census. Controlling for current region, the effect of mother's slave status is -.25 for the women and -.16 for the men.

Table X calculates the effects of grandmother's slavery status on literacy and in-school status for children in households in the 1920 Census. Controlling for current region (and using whites to control for the effect of being born inside the South), the effect of having a grandmother born into slavery reduces the probability of being literate by 13 percent and the probability of being in school by 9 percent.

Overall, the effects of slave status on literacy and schooling are somewhat different when I use whites as a control than when I simply compare blacks inside and outside the South. When I use whites as a control, I still find substantial upward convergence between the grandchildren of slaves and the 
grandchildren of free blacks, but not complete convergence. Which estimate to believe, if any, is open to debate. But however I calculate these estimates, I find substantial convergence within two generations.

\section{Transmission Coefficients}

The convergence observed in the previous section implies that within family transmission rates of literacy and schooling are substantially less than one and that considerable regression to the mean occurs within two generations. I turn now to measuring these transmission rates and asking whether an AR1 transmission process fits the data. Tables XI and XII calculate various transmission rates (of literacy and occupational income score) from parents and grandparents to children. In all cases I am simply regressing child's outcome (literacy or occupational income score) on parent's outcome and in some cases on grandparent's outcome.

An important caveat to this set of results is that I can only calculate the transmission rates from parents or grandparents when the children still live in the same household as the parents or grandparents. This is not necessarily a problem for estimating the transmission of literacy from parents to children, given that many children learn to read before leaving their parents' home. This caveat is more of a problem for transmission of occupational income score since occupations and hence occupational scores continue to change after children leave their parents' household.

Table XI shows the coefficients of transmission for literacy and occupational income score for the 1880 households. The coefficient of transmission for literacy from mothers to children is .32 for the white children and .45 for the black children. When I limit the sample to households where the mother's mother is present, the coefficient on mother's literacy is .29 and the coefficient on grandmother's literacy is .17. While this result implies that grandmother's outcome is extremely important in determining the child's outcome, it is possible that the impact of grandmother's literacy is particularly high in this selected sample of households where the grandmother is actually present.

The results for transmission of occupational income score are shown in columns (5)-(8). Since I examine only children born after 1865, most of the children in the sample are too young to have an occupation listed. In this sample, the coefficient of transmission for income score is .38 for the white households and .45 for the black households. These magnitudes are consistent with the existing literature on transmission of income from father's to sons. My transmission rates are on the higher end of existing estimates. This seems plausible given that my income score is constant within occupation. Income itself 
includes both individual income shocks within occupation and occupation level shocks over time and I am forced to exclude both sources of variation.

Column (8) of Table XI regresses the child's income score on father's income score and grandfather's income score. Within this small subset of households, the effect of the grandfather's income score is small (at .07) and insignificant. This provides some weak evidence in favor of the hypothesis that transmission of income or socioeconomic status can be modeled as an AR1 process.

Table XII examines transmission of literacy and income scores within the 1920 households. Columns (1) -(4) shows that the literacy coefficient of transmission from mothers to children is dramatically lower in the 1920 households than in the 1880 households. Figure V shows transmission rates of literacy by birth cohort of the child. The transmission rate falls dramatically with each cohort both for black and for white households. This drop in the transmission rate is almost surely related to the fact that literacy rates are approaching 100 percent for all whites and for non-Southern blacks. However, the drop in the transmission rate need not be an algebraic consequence of the rise in literacy. With each successive cohort the children who are not literate look more and more like a random sample of the population rather than simply the set of children with illiterate parents.

The transmission coefficients for income score in columns (5)-(8) echo the results from the 1880 data. Transmission coefficients are higher for blacks than whites and grandfather's income score does not matter controlling for father's income score.

\section{Results for the Merged Sample of 1880 and 1920 Households}

One of the obstacles to studying transmission of income or SES over multiple generations is that it is unusual to have data for three (or more) generations of adults in the same data set. To attempt to mitigate this problem I have merged some of the data for the 1920 IPUMs households back into the 1880 Census.

I merge the data sets by taking male heads of household (fathers) in the 19201 percent sample and locating them in the 1880100 percent sample. I did not attempt to trace any of the women in the 1920 sample due to the high likelihood of name changes at time of marriage. I merge the data for the fathers based on first name, last name, year of birth, place of birth, mother's place of birth and father's place of birth. This is a surprisingly unique combination of variables; it is rare for any two individuals to have 
exactly the same data for all six fields above. This happens in at most 1 percent of cases in the 1920 data and when it does occur I drop the data point.

The objective is to take men who are heads of household in 1920 and locate them in their 1880 household record, when most of them were children. I limit the potential sample for the merge to fathers who have a reported occupation, are U.S. born, are ages 40-60 in 1920 (0-20 in 1880) and have at least once male son 18 or older in their 1920 household. This last limitation is so that I can obtain some measure of the income score for the children in the 1920 households (the grandchildren of the 1880 householders).

The 1880100 percent sample includes a National Index which allows me to search for the fathers not just in their 1920 state, but in all US states. The search software on the CDs also allows me to check for various possible spellings of the first names, e.g. Charlie and Charles. Permitting the first names to vary in this way did help create additional matches and did not often create multiple 1880 matches for the same 1920 observation.

There were 16,238 fathers (black and white) in the 1920 data for the potential match. As shown in Table XIII, I successfully matched 1,854 of these fathers for an 11 percent success rate. ${ }^{21}$ While this match rate is low, Table XIII shows that the matched and unmatched observations have similar levels of literacy and occupational income scores.

The key piece of data that I pull from the 1880 household is the head's occupation. This is the occupation of the grandfather of the children in the 1920 households. The occupation is a text field in the 1880 data, but I coded it to match the occupation codes created in the IPUMs data. I then merged in occupational income scores and my 0-1 variable for manual occupation.

In Table XIV I examine transmission of SES from grandparents to grandchildren holding father's SES constant. ${ }^{22}$ The first three columns are for black families. In column (1), I regress child's income score on father's and grandfather's income scores. The coefficient on father's score is .55 with a t-statistic of 4.3, while the coefficient on the grandfather's score is .06 and is not statistically significant. In the absence of measurement error, and under the null of the AR1 model of SES transmission, we would

\footnotetext{
${ }^{21}$ An additional 3 percent of the fathers were matched, but were not living with their parents in 1880 . Most of these had either formed their own households already or were working as laborers while living with a different family.

${ }^{22}$ Unfortunately the sample is to small to allow me to compare grandchildren of slaves to grandchildren of free blacks within the merged sample.
} 
expect the coefficient on grandfather's SES to be 0. Column (4) for the whites yields very similar coefficients. I interpret the regressions as evidence that the AR1 model of SES transmission is roughly correct.

Columns (2) and (5) include only the grandfather's score. Here I wish to test whether the coefficient on the grandfather's score is equal to the square of the coefficient on the father's score. For black children, the coefficient on grandfather's score is negative and insignificant and for the white children the coefficient is .13. In both cases, the coefficient on grandfather's score is actually smaller than the square of the coefficient on the father's income score. Taken at face value, these estimates would suggest that transmission of SES over two generations actually degrades even faster than a simple AR1 process. However, given the large standard errors and the measurement error inherent in the occupational income score this finding is at most suggestive.

In columns (3) and (6) I drop all observations for which the 1920 head of household is working as a farmer or farm laborer. Given that a large fraction of people work in agriculture, some of whom pass on the "family farm" to their children, it may be important to consider transmission outside of the farm sector. Predictably, transmission coefficients are much lower among the non-farmers. The transmission coefficient is .20 for blacks and .23 for whites.

\section{Conclusion}

This paper has demonstrated that on certain basic outcome measures, namely literacy, schooling, and occupation, the descendants of slaves "caught-up" to the descendants of free blacks within two generations. This statement is particularly true when we identify the effects of slave status by comparing descendants of free blacks and slaves who reside outside of the South. If we instead measure the progress of free blacks and slaves (and their descendants) relative to whites born in the same regions, then we find partial but not complete convergence.

This convergence is consistent with the high degree of social mobility implied by modern estimates of parent-child income and education correlations. When I regress son's SES on father's and grandfather's SES, I find that father's SES has a coefficient of .20 to .55 but grandfather's SES only matters a small amount controlling for the father's outcome. This is evidence of strong father-son correlations which decay rapidly with each successive generation. 
The one outcome that shows only modest intra-black convergence is female headed household status for children. The large 1880 gap in female headed household rates between free black families and former slave families supports the hypothesis that the plantation system hurt the stability of black families. The persistence (into 1920) of the slavery effect on female headed households is more surprising.

If there is convergence, what is the cause? For literacy, one natural explanation would be the rise of public schools and the passage of mandatory schooling laws. Today's high mobility of income and wealth may also be driven in part by public schools and the availability of high quality public universities, and in part by other "great equalizers" like cable television or the internet. High social mobility in postBellum America or in the modern OECD need not be an inevitable outcome that is independent of government institutions. Social activism could be just as important or more important than other market forces in creating convergence.

A major topic for future research is whether or not convergence within two generations is a common phenomenon observed after social barriers between groups are removed. This has particular relevance for the U.S. given the $20^{\text {th }}$ Century's dismantling of racial barriers in access to schooling and jobs. A natural extension of this paper would be to attempt to tie these results to the modern literature on black-white wage and education differentials. If political changes in the 1960s and 1970s freed black workers from institutionalized discrimination, then perhaps black-white convergence might occur within one or two generations from today. 


\section{References}

Almond, Douglas V., Kenneth Y. Chay, and Michael Greenstone, "Civil Rights, the War on Poverty, and Black-White Convergence in Mississippi," mimeo, 2001.

Altonji, Joseph G. and Thomas A. Dunn, "Relationships Among the Family Incomes and Labor Market Outcomes of Relatives," Research in Labor Economics, 12 (1991), 269-310.

Angrist, Joshua D., "How Do Sex Ratios Affect Marriage and Labor Markets? Evidence from America's Second Generation," Quarterly Journal of Economics, 117 (August 2002), 997 - 1038.

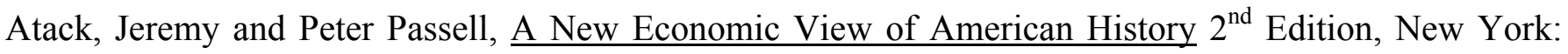
W.W. Norton and Company, 1994.

Bancroft, Frederic, Slave Trading in the Old South. Baltimore: J.H. Furst Company, 1931.

Bjorklund Anders and Markus Jantii, "Intergenerational Mobility in Sweden Compared to the United States," American Economic Review, 87 (1997), 377-386.

Brown, Charles C., 1984 "Black-White Earnings Ratios Since the Civil Rights Act of 1964: The Importance of Labor Market Dropouts," Quarterly Journal of Economics, 95(1), 31-44.

Chandra, Amitabh "Is Convergence in The Racial Wage Gap Illusory?," mimeo, Dartmouth College, 2001.

Charles, Kerwin and Erik Hurst, "The Correlation of Wealth Across Generations,” 2001.

Darity, William, Dietrich J., and Guilkey D.K., "Persistent Advantage or Disadvantage?: Evidence in Support of the Intergenerational Drag Hypothesis," American Journal of Economics and Sociology, 60 (April 2001).

Donohue, John J. and James J. Heckman, "Continuous versus Episodic Change: The Impact of Affirmative Action and Civil Rights Policy on the Economic Status of Blacks," Journal of Economic Literature, December 1991, 29 (4), pp. 1603-44. 
DuBois, W.E.B., The Philadelphia Negro: A Social Study, New York: Benjamin Blom, 1899.

DuBois, W.E.B., The Souls of Black Folk. 1903.

Fogel, Robert W. and Stanley L. Engerman, Time on the Cross: The Economics of American Negro Slavery. Boston: Little, Brown, 1974.

Gould, Virginia Meacham, Chained to the Rock of Adversity: To Be Free, Black, and Female in the Old

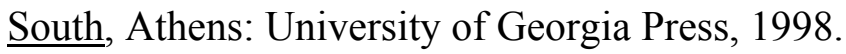

Heckman, James J., Thomas Lyons and Petra Todd, "Understanding Black-White Wage Differentials 1960-90," American Economic Review 90(2), 344-49.

Hodges, Graham Russell, Slavery and Freedom in the Rural North. Madison: Madison House Publishers, 1997.

Margo, Robert A., "Educational Achievement in Segregated School Systems: The Effect of Separate But Equal,” American Economic Review, 76 (September 1986), 794-801.

Margo, Robert A., Race and Schooling in the South, 1880-1950: An Economic History. Chicago: University of Chicago Press, 1990.

Margo, Robert A., "The South as an Economic Problem: Fact or Fiction?," in L. Griffin and D. Doyle, eds, The South as an American Problem. Athens: University of Georgia Press, 1995.

Margo, Robert A., "The North-South Wage Gap, Before and After the Civil War," National Bureau of Economic Research Working Paper Series, Number 8778, 2002.

McManus, Edgar J., A History of Negro Slavery in New York. Syracuse: Syracuse University Press, 1966.

Mulligan, Casey B., Parental Priorities and Economic Inequality, Chicago: University of Chicago Press, 1997. 
Neal, Derek and William Johnson, "The Role of Premarket Factors in Black-White Wage Differences," Journal of Political Economy, 104(5), 869-95.

Olwell, Robert, Becoming Free: Manumission and the Genesis of a Free Black Community in South Carolina, 1740-90 in Jane G. Landers ed., Against the Odds: Free Blacks in the Slave Societies of the Americas. London: Frank Cass, 1996.

Phillips, Christopher, Freedom's Port: The African American Community of Baltimore 1790-1860. Chicago: University of Illinois Press, 1997.

Ransom, Roger and Richard Sutch, One Kind of Freedom: The Economics of Emancipation. New York: Cambridge University Press, 1977.

Smith, James P. "Race and Human Capital," American Economic Review, 74 (September 1984), 685-98.

Smith, James P. and Finis R. Welch, "Black Economic Progress After Myrdal," Journal of Economic Literature, 27(2) (June, 1989), 519-564.

Solon, Gary, "Intergenerational Income Mobility in the United States," American Economic Review, 82 (1992), 393-408.

Solon, Gary, "Intergenerational Mobility in the Labor Market," in Orley Ashenfelter and David Card eds., Handbook of Labor Economics, Vol 3. Elsevier Science B.V., 1999.

Washinton, Booker T., Up From Slavery. New York: Doubleday, 1901.

Wright, Gavin, Old South, New South. New York: Basic Books, 1986.

Zilervirsmit, Arthur, The First Emancipation: The Abolition of Slavery in the North. Chicago: University of Chicago Press, 1967.

Zimmerman, David J., "Regression Toward Mediocrity in Economic Stature," American Economic Review, 82(1992), 409-429. 


\section{Table I}

\section{Panel A: Means For Children in 1880 Census}

\begin{tabular}{lrrrrrr}
\hline \hline & \multicolumn{3}{c}{ Black Households } & \multicolumn{3}{c}{ White Households } \\
& $\mathrm{N}$ & Mean & Std. Dev. & $\mathrm{N}$ & Mean & Std. Dev. \\
Child's literacy & 7,442 & 0.35 & 0.48 & 34,752 & 0.85 & 0.36 \\
Child is in school & 12,342 & 0.32 & 0.47 & 55,570 & 0.73 & 0.44 \\
Mother was born a slave & 12,342 & 0.97 & 0.16 & 55,570 & 0.42 & 0.49 \\
Child Age & 12,342 & 10.52 & 2.53 & 55,570 & 10.66 & 2.52 \\
Mother's age & 11,868 & 36.57 & 8.69 & 53,798 & 38.47 & 7.66 \\
Number of siblings & 12,342 & 4.00 & 2.17 & 55,570 & 3.68 & 2.04 \\
Child is Male & 12,342 & 0.51 & 0.50 & 55,570 & 0.51 & 0.50 \\
Current region is South & 12,342 & 0.94 & 0.26 & 55,570 & 0.40 & 0.48 \\
Curent region is Northeast & 12,342 & 0.03 & 0.14 & 55,570 & 0.25 & 0.43 \\
Current region is Central & 12,342 & 0.03 & 0.22 & 55,570 & 0.31 & 0.48 \\
Current region is West & 12,342 & 0.00 & 0.04 & 55,570 & 0.03 & 0.17 \\
& & & & & & \\
& & & & & & \\
Mother's literacy & 11,868 & 0.17 & 0.38 & 53,798 & 0.87 & 0.34 \\
Father's literacy & 10,550 & 0.22 & 0.41 & 51,660 & 0.89 & 0.31 \\
Father has manual job & 11,859 & 0.96 & 0.20 & 53,323 & 0.84 & 0.37 \\
Father's occupational income score & 10,396 & 15.24 & 5.15 & 50,881 & 19.88 & 10.90 \\
& & & & & & \\
\hline \hline
\end{tabular}

\section{Panel B: Means For Children 1920 Census}

\begin{tabular}{lrrrrrr}
\hline \hline & \multicolumn{3}{c}{ Black Households } & \multicolumn{3}{c}{ White Households } \\
Child's literacy & 13,799 & 0.83 & 0.37 & 84,713 & 0.98 & 0.13 \\
Child is in school & 13,119 & 0.67 & 0.47 & 77,822 & 0.81 & 0.40 \\
Grandmother was born a slave & 16,647 & 0.98 & 0.14 & 101,204 & 0.49 & 0.50 \\
Child Age & 16,647 & 14.69 & 5.19 & 101,204 & 14.93 & 5.28 \\
Mother's age & 16,647 & 42.57 & 5.45 & 101,204 & 43.37 & 5.50 \\
Number of siblings & 16,647 & 4.10 & 2.52 & 101,204 & 3.28 & 2.21 \\
Child is Male & 16,647 & 0.51 & 0.50 & 101,204 & 0.53 & 0.50 \\
Current region is South & 16,647 & 0.91 & 0.29 & 101,204 & 0.43 & 0.50 \\
Curent region is Northeast & 16,647 & 0.04 & 0.19 & 101,204 & 0.19 & 0.39 \\
Current region is Central & 16,647 & 0.05 & 0.21 & 101,204 & 0.31 & 0.46 \\
Current region is West & 16,647 & 0.00 & 0.07 & 101,204 & 0.07 & 0.26 \\
& & & & & & \\
& & & & & & \\
Mother's literacy & 16,647 & 0.67 & 0.47 & 101,204 & 0.96 & 0.19 \\
Father's literacy & 13,300 & 0.66 & 0.47 & 92,315 & 0.95 & 0.22 \\
Father has manual job & 13,103 & 0.95 & 0.21 & 89,748 & 0.79 & 0.41 \\
Father's occupational income score & 13,155 & 16.17 & 5.82 & 90,526 & 22.65 & 11.57 \\
\hline \hline
\end{tabular}

Notes: All data are from 1880 and 1920 IPUMS 1 percent samples of the Census of Population. 1880 sample includes children ages 7-15. (Observations for children under age 7 have neither literacy measure nor the schooling measure. Children over 15 were born before the end of the Civil War. ) Means for mothers and fathers are taken at the child level, ie the means are weighted by the number of children in the family.

1920 sample includes any children ages 7-35 within households. South dummy is defined as all former slave states. 


\section{Table II \\ Effect of Own Slave Status, Mother's or \\ Grandmother's Slave Status on Literacy}

This table shows various OLS estimates of the effect of being born into slavery (or having an ancestor born into slavery) on literacy. The samples are limited to blacks in the 1880 and 1920 Censuses. Means and standard deviations of the dependent variables for former slaves and free (pre-1865) blacks or their descendants are shown in columns (4) and (5). "Effects" of slave status are calculated by using an OLS regression of literacy on own, mother's or grandmother's slave status. The final column shows the analogous effect of born in a slave state for whites.

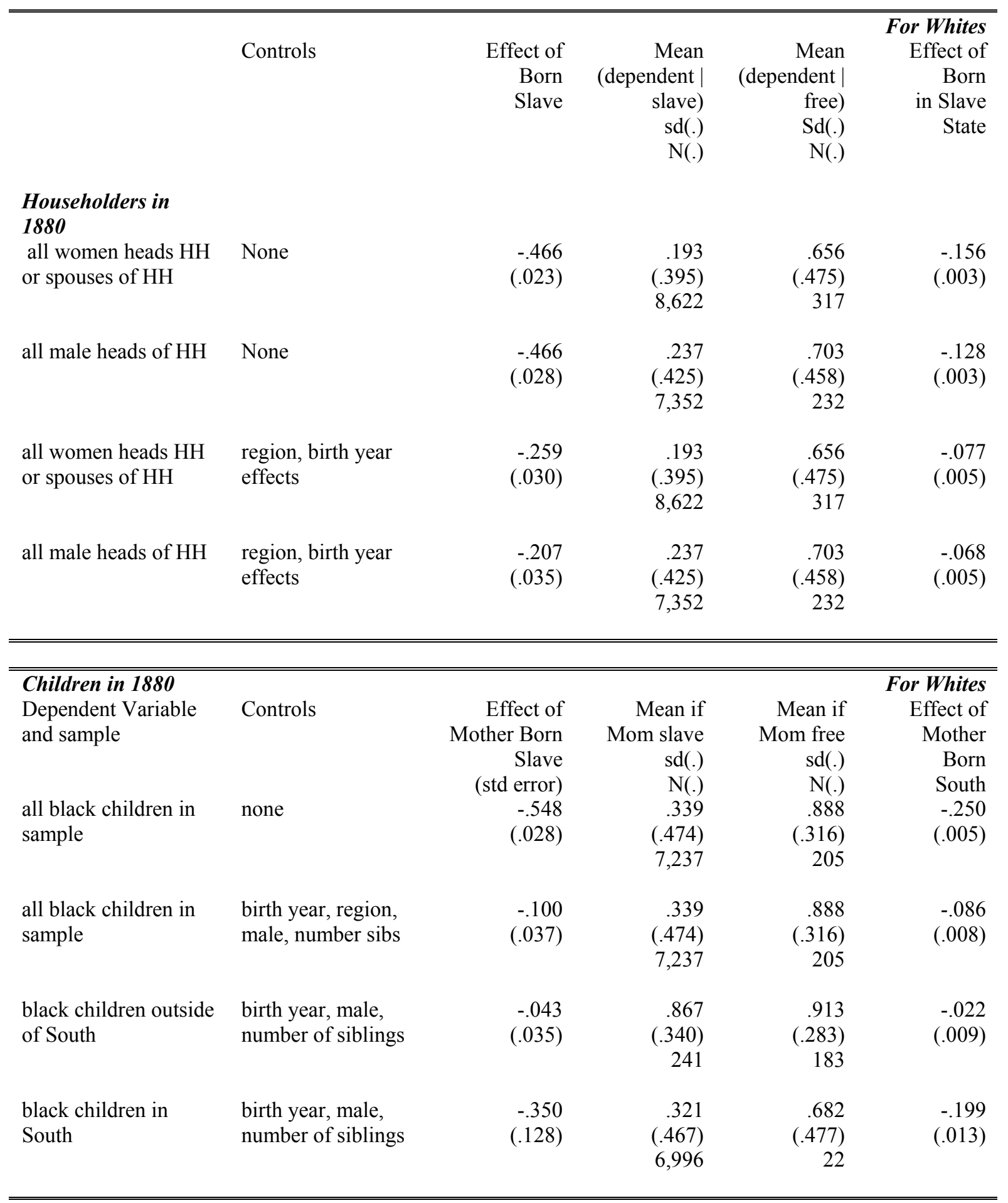




\section{Table II (continued) Effect of Slave Status on Literacy}

\begin{tabular}{|c|c|c|c|c|c|}
\hline $\begin{array}{l}\text { Householders in } \\
1920\end{array}$ & Controls & $\begin{array}{r}\text { Effect of } \\
\text { Mother Born } \\
\text { Slave } \\
\text { (std error) }\end{array}$ & $\begin{array}{r}\text { Mean if } \\
\text { Mom slave } \\
\text { sd(.) } \\
\mathrm{N}(.)\end{array}$ & $\begin{array}{r}\text { Mean if } \\
\text { Mom free } \\
\text { sd(.) } \\
\mathrm{N}(.)\end{array}$ & $\begin{array}{r}\text { For Whites } \\
\text { Effect of } \\
\text { Mother } \\
\text { Born } \\
\text { South }\end{array}$ \\
\hline $\begin{array}{l}\text { all black householders } \\
\text { in sample (ages 35- } \\
55 \text { ) }\end{array}$ & none & $\begin{array}{r}-.275 \\
(.013)\end{array}$ & $\begin{array}{r}.656 \\
(.475) \\
13,694\end{array}$ & $\begin{array}{r}.931 \\
(.253) \\
495\end{array}$ & $\begin{array}{l}-.050 \\
(.002)\end{array}$ \\
\hline $\begin{array}{l}\text { all black householders } \\
\text { in sample (ages 35- } \\
\text { 55) }\end{array}$ & $\begin{array}{l}\text { birth year, region, } \\
\text { male, number } \\
\text { children }\end{array}$ & $\begin{array}{r}-.099 \\
(.015)\end{array}$ & $\begin{array}{r}.656 \\
(.475) \\
13,694\end{array}$ & $\begin{array}{r}.931 \\
(.253) \\
495\end{array}$ & $\begin{array}{l}-.020 \\
(.002)\end{array}$ \\
\hline $\begin{array}{l}\text { black householders } \\
\text { outside of South (ages } \\
35-55 \text { ) } \\
\text { black householders in } \\
\text { South (ages 35-55) }\end{array}$ & $\begin{array}{l}\text { birth year, male, } \\
\text { number of children } \\
\text { birth year, male, } \\
\text { number of children }\end{array}$ & $\begin{array}{r}-.062 \\
(.015) \\
\\
-.235 \\
(.035)\end{array}$ & $\begin{array}{r}.889 \\
(.315) \\
1,877 \\
.619 \\
(.486) \\
11,817\end{array}$ & $\begin{array}{r}.945 \\
(.227) \\
403 \\
.870 \\
(.339) \\
92\end{array}$ & $\begin{array}{r}.001 \\
(.002) \\
-.058 \\
(.003)\end{array}$ \\
\hline Children in 1920 & Controls & $\begin{array}{r}\text { Effect of } \\
\text { Grandmother } \\
\text { Born } \\
\text { Slave } \\
\text { (std error) }\end{array}$ & $\begin{array}{r}\text { Mean if } \\
\text { Grandmother } \\
\text { slave } \\
\text { sd(.) } \\
\mathrm{N}(.)\end{array}$ & $\begin{array}{r}\text { Mean if } \\
\text { Mom free } \\
\text { sd(.) } \\
\mathrm{N}(.)\end{array}$ & $\begin{array}{r}\text { For Whites } \\
\text { Effect of } \\
\text { Grandmother } \\
\text { Born } \\
\text { South }\end{array}$ \\
\hline $\begin{array}{l}\text { all black children in } \\
\text { sample ages } 10-25\end{array}$ & none & $\begin{array}{r}-.155 \\
(.010)\end{array}$ & $\begin{array}{r}.831 \\
(.375) \\
13,509\end{array}$ & $\begin{array}{r}.986 \\
(.120) \\
276\end{array}$ & $\begin{array}{l}-.024 \\
(.001)\end{array}$ \\
\hline $\begin{array}{l}\text { all black children in } \\
\text { sample ages } 10-25\end{array}$ & $\begin{array}{l}\text { birth year, region, } \\
\text { male, number sibs }\end{array}$ & $\begin{array}{r}-.030 \\
(.011)\end{array}$ & $\begin{array}{r}.831 \\
(.375) \\
13,509\end{array}$ & $\begin{array}{r}.986 \\
(.120) \\
276\end{array}$ & $\begin{array}{l}-.008 \\
(.001)\end{array}$ \\
\hline $\begin{array}{l}\text { black children outside } \\
\text { of South ages } 10-25\end{array}$ & $\begin{array}{l}\text { birth year, male, } \\
\text { number of siblings }\end{array}$ & $\begin{array}{r}-.005 \\
(.006)\end{array}$ & $\begin{array}{r}.990 \\
(.099) \\
1,005\end{array}$ & $\begin{array}{r}.995 \\
(.067) \\
221\end{array}$ & $\begin{array}{r}.002 \\
(.001)\end{array}$ \\
\hline $\begin{array}{l}\text { black children in } \\
\text { South ages } 10-25\end{array}$ & $\begin{array}{l}\text { birth year, male, } \\
\text { number of siblings }\end{array}$ & $\begin{array}{r}-.121 \\
(.036)\end{array}$ & $\begin{array}{r}.817 \\
(.386) \\
12,504\end{array}$ & $\begin{array}{r}.945 \\
.229) \\
55\end{array}$ & $\begin{array}{l}-.023 \\
(.002)\end{array}$ \\
\hline
\end{tabular}




\section{Table III}

\section{Effect of Mother's or Grandmother's Slave Status on Probability of Being in School For Children in Black Households in 1880 and 1920 Census IPUMS}

This table compares outcomes for black children with mothers (grandmothers) who were former slaves versus outcomes for black children with mothers (grandmothers) born free. These children are born one (two) generations after slavery. "Effects" of mother's (grandmother's) slave status are calculated by using an OLS regression of "in-school" on mother's (grandmother's) former slave status.

\begin{tabular}{|c|c|c|c|c|c|}
\hline Children in 1880 & & $\begin{array}{r}\text { Effect of } \\
\text { Mother Born } \\
\text { Slave } \\
\text { (std error) }\end{array}$ & $\begin{array}{r}\text { Mean if } \\
\text { Mom slave } \\
\text { sd(.) } \\
\mathrm{N}(.)\end{array}$ & $\begin{array}{r}\text { Mean if } \\
\text { Mom free } \\
\operatorname{sd}(.) \\
\mathrm{N}(.)\end{array}$ & $\begin{array}{r}\text { For Whites } \\
\text { Effect of } \\
\text { Grandmother } \\
\text { Born } \\
\text { South }\end{array}$ \\
\hline $\begin{array}{l}\text { all black children in } \\
\text { sample, ages } 7-15\end{array}$ & none & $\begin{array}{l}-.360 \\
(.036)\end{array}$ & $\begin{array}{r}.309 \\
(.462) \\
12,025\end{array}$ & $\begin{array}{r}.669 \\
(.471) \\
317\end{array}$ & $\begin{array}{r}-.235 \\
(.005)\end{array}$ \\
\hline $\begin{array}{l}\text { all black children in } \\
\text { sample, ages } 7-15\end{array}$ & $\begin{array}{l}\text { birth year, region, } \\
\text { male, number sibs }\end{array}$ & $\begin{array}{r}-.084 \\
(.042)\end{array}$ & $\begin{array}{r}.309 \\
(.462) \\
12,025\end{array}$ & $\begin{array}{r}.669 \\
(.471) \\
317\end{array}$ & $\begin{array}{r}-.067 \\
(.009)\end{array}$ \\
\hline $\begin{array}{l}\text { black children outside } \\
\text { of South, ages } 7-15\end{array}$ & $\begin{array}{l}\text { birth year, male, } \\
\text { number of siblings }\end{array}$ & $\begin{array}{r}-.048 \\
(.046)\end{array}$ & $\begin{array}{r}0.642 \\
(.480) \\
408\end{array}$ & $\begin{array}{r}0.691 \\
(.463) \\
285\end{array}$ & $\begin{array}{r}-.037 \\
(.011)\end{array}$ \\
\hline $\begin{array}{l}\text { black children in } \\
\text { South, ages } 7-15\end{array}$ & $\begin{array}{l}\text { birth year, male, } \\
\text { number of siblings }\end{array}$ & $\begin{array}{r}-.157 \\
(.122)\end{array}$ & $\begin{array}{r}.297 \\
(.457) \\
11,617\end{array}$ & $\begin{array}{r}.469 \\
(.507) \\
32\end{array}$ & $\begin{array}{r}-.141 \\
(.016)\end{array}$ \\
\hline Children in 1920 & & $\begin{array}{r}\text { Effect of } \\
\text { Grandmother } \\
\text { Born } \\
\text { Slave } \\
\text { (std error) }\end{array}$ & $\begin{array}{r}\text { Mean if } \\
\text { Grandma } \\
\text { slave } \\
\text { sd(.) } \\
\mathrm{N}(.)\end{array}$ & $\begin{array}{r}\text { Mean if } \\
\text { Mom free } \\
\operatorname{sd}(.) \\
\mathrm{N}(.)\end{array}$ & $\begin{array}{r}\text { For Whites } \\
\text { Effect of } \\
\text { Grandmother } \\
\text { Born } \\
\text { South }\end{array}$ \\
\hline $\begin{array}{l}\text { all black children in } \\
\text { sample ages } 7-18\end{array}$ & none & $\begin{array}{l}-.088 \\
(.037)\end{array}$ & $\begin{array}{r}.664 \\
(.472) \\
12,862\end{array}$ & $\begin{array}{r}.752 \\
(.433) \\
242\end{array}$ & $\begin{array}{r}-.022 \\
(.003)\end{array}$ \\
\hline $\begin{array}{l}\text { all black children in } \\
\text { sample ages } 7-18\end{array}$ & $\begin{array}{l}\text { birth year, region, } \\
\text { male, number sibs }\end{array}$ & $\begin{array}{r}-.019 \\
(.036)\end{array}$ & $\begin{array}{r}.664 \\
(.472) \\
12,862\end{array}$ & $\begin{array}{r}.752 \\
(.433) \\
242\end{array}$ & $\begin{array}{r}-.011 \\
(.005)\end{array}$ \\
\hline $\begin{array}{l}\text { black children outside } \\
\text { of South ages 7-18 }\end{array}$ & $\begin{array}{l}\text { birth year, male, } \\
\text { number of siblings }\end{array}$ & $\begin{array}{r}-.003 \\
(.037)\end{array}$ & $\begin{array}{r}.765 \\
(.424) \\
800\end{array}$ & $\begin{array}{r}.768 \\
(.423) \\
194\end{array}$ & $\begin{array}{r}.013 \\
(.006)\end{array}$ \\
\hline $\begin{array}{l}\text { black children in } \\
\text { South ages } 7-18\end{array}$ & $\begin{array}{l}\text { birth year, male, } \\
\text { number of siblings }\end{array}$ & $\begin{array}{r}-.067 \\
(.096)\end{array}$ & $\begin{array}{r}.658 \\
(.475) \\
12,062\end{array}$ & $\begin{array}{r}.688 \\
(.468) \\
48\end{array}$ & $\begin{array}{r}-.027 \\
(.008)\end{array}$ \\
\hline
\end{tabular}

Notes: 1880 sample includes black children in households in IPUMS. Mother's former slave status is imputed from year and state of birth. All of the mothers are born before 1865 and all of the children are born after 1865 . (Children older than 15 and households with mothers younger than 15 are dropped .) 1920 sample includes children ages 7-18 in IPUMS sample.

"In-school" status is determined from the Census question which asked whether or not a person "attended school within the past year." 
Table IIIa

\section{Effect of Grandmother's Slave Status on Number of Months in School For Children in Black Households in 1900 Census IPUMS}

This table compares outcomes for black children with mothers who were former slaves versus outcomes for black children with mothers born free. These children are born two generations after slavery. "Effects" of grandmother's slave status are calculated by using an OLS regression of "in-school" on grandmother's former slave status.

\begin{tabular}{|c|c|c|c|c|}
\hline Children in 1900 & & $\begin{array}{r}\text { Effect of } \\
\text { Grandmother } \\
\text { Born } \\
\text { Slave } \\
\text { (std error) }\end{array}$ & $\begin{array}{r}\text { Mean if } \\
\text { Grandmother } \\
\text { slave } \\
\text { sd(.) } \\
\mathrm{N}(.)\end{array}$ & $\begin{array}{r}\text { Mean if } \\
\text { Grandmother } \\
\text { free } \\
\mathrm{sd}(.) \\
\mathrm{N}(.)\end{array}$ \\
\hline $\begin{array}{l}\text { all black children in } \\
\text { sample, ages } 7-15\end{array}$ & none & $\begin{array}{r}-3.229 \\
(.468)\end{array}$ & $\begin{array}{r}4.104 \\
(6.176) \\
1,821\end{array}$ & $\begin{array}{r}7.333 \\
(2.426) \\
60\end{array}$ \\
\hline $\begin{array}{l}\text { all black children in } \\
\text { sample, ages } 7-15\end{array}$ & $\begin{array}{l}\text { birth year, region, } \\
\text { male, number sibs }\end{array}$ & $\begin{array}{r}-.307 \\
(.538)\end{array}$ & $\begin{array}{r}4.104 \\
(6.176) \\
1,821\end{array}$ & $\begin{array}{r}7.333 \\
(2.426) \\
60\end{array}$ \\
\hline $\begin{array}{l}\text { black children outside } \\
\text { of South, ages } 7-15\end{array}$ & $\begin{array}{l}\text { birth year, male, } \\
\text { number of siblings }\end{array}$ & $\begin{array}{r}.636 \\
(.542)\end{array}$ & $\begin{array}{r}8.080 \\
(2.152) \\
87\end{array}$ & $\begin{array}{r}7.327 \\
(2.593) \\
49\end{array}$ \\
\hline $\begin{array}{l}\text { black children in } \\
\text { South, ages } 7-15\end{array}$ & $\begin{array}{l}\text { birth year, male, } \\
\text { number of siblings }\end{array}$ & $\begin{array}{l}-2.940 \\
(.692)\end{array}$ & $\begin{array}{r}3.905 \\
(6.245) \\
1,734\end{array}$ & $\begin{array}{r}7.364 \\
(1.567) \\
11\end{array}$ \\
\hline
\end{tabular}




\section{Table IV}

\section{Effect of Mother's or Grandmother's Slave Status on Probability of Being in Female Headed Household For Black Children in 1880 and 1920}

This table compares female headed household status for black children with mothers (grandmothers) who were former slaves versus female HH status for black children with mothers (grandmothers) born free. These children are born one (two) generations after slavery. "Effects" of mother's (grandmother's) slave status are calculated by using an OLS regression of female headed household on mother's (grandmother's) former slave status.

\begin{tabular}{|c|c|c|c|c|}
\hline Children in 1880 & IPUMS SAMPLE & $\begin{array}{r}\text { Effect of } \\
\text { Mother Born } \\
\text { Slave } \\
\text { (std error) }\end{array}$ & $\begin{array}{r}\text { Mean if } \\
\text { Mom slave } \\
\text { sd(.) } \\
\mathrm{N}(.)\end{array}$ & $\begin{array}{r}\text { Mean if } \\
\text { Mom free } \\
\operatorname{sd}(.) \\
\mathrm{N}(.)\end{array}$ \\
\hline $\begin{array}{l}\text { all black children in } \\
\text { sample, ages } 0-15\end{array}$ & $\begin{array}{l}\text { controls } \\
\text { none }\end{array}$ & $\begin{array}{r}.041 \\
(.018)\end{array}$ & $\begin{array}{r}.135 \\
(.341) \\
24,911\end{array}$ & $\begin{array}{r}.094 \\
(.291) \\
652\end{array}$ \\
\hline $\begin{array}{l}\text { all black children in } \\
\text { sample, ages } 0-15\end{array}$ & $\begin{array}{l}\text { birth year, region, } \\
\text { male, number sibs }\end{array}$ & $\begin{array}{r}.089 \\
(.026)\end{array}$ & $\begin{array}{r}.135 \\
(.341) \\
24,911\end{array}$ & $\begin{array}{r}.094 \\
(.291) \\
652\end{array}$ \\
\hline $\begin{array}{l}\text { black children outside } \\
\text { of South, ages } 0-15\end{array}$ & $\begin{array}{l}\text { birth year, male, } \\
\text { number of siblings }\end{array}$ & $\begin{array}{r}.068 \\
(.028)\end{array}$ & $\begin{array}{r}.158 \\
(.365) \\
780\end{array}$ & $\begin{array}{r}.096 \\
.295) \\
591\end{array}$ \\
\hline $\begin{array}{l}\text { black children in } \\
\text { South, ages } 0-15\end{array}$ & $\begin{array}{l}\text { birth year, male, } \\
\text { number of siblings }\end{array}$ & $\begin{array}{r}.079 \\
(.051)\end{array}$ & $\begin{array}{r}.134 \\
(.341) \\
24,131\end{array}$ & $\begin{array}{r}.066 \\
(.250) \\
61\end{array}$ \\
\hline Children in 1880 & $100 \%$ SAMPLE & $\begin{array}{r}\text { Effect of } \\
\text { Mother Born } \\
\text { Slave } \\
\text { (std error) }\end{array}$ & $\begin{array}{r}\text { Mean if } \\
\text { Mom slave } \\
\text { sd(.) } \\
\mathrm{N}(.)\end{array}$ & $\begin{array}{r}\text { Mean if } \\
\text { Mom free } \\
\text { sd(.) } \\
\mathrm{N}(.)\end{array}$ \\
\hline $\begin{array}{l}\text { all black children in } \\
\text { New England, } \\
\text { ages } 0-15\end{array}$ & $\begin{array}{l}\text { controls } \\
\text { none }\end{array}$ & $\begin{array}{l}.0004 \\
(.015)\end{array}$ & $\begin{array}{r}.125 \\
(.330) \\
1293\end{array}$ & $\begin{array}{r}.124 \\
(.330) \\
2401\end{array}$ \\
\hline $\begin{array}{l}\text { all black children in } \\
\text { New York City Area, } \\
\text { ages } 0-15\end{array}$ & none & $\begin{array}{r}.082 \\
(.021)\end{array}$ & $\begin{array}{r}.188 \\
(.391) \\
786\end{array}$ & $\begin{array}{r}.107 \\
(.309) \\
2139\end{array}$ \\
\hline
\end{tabular}




\section{Table IV (continued) \\ Effect of Grandmother Slave Status on \\ Child Living in Female Headed Household}

\begin{tabular}{|c|c|c|c|c|}
\hline Children in 1920 & IPUMS SAMPLE & $\begin{array}{r}\text { Effect of } \\
\text { Grandmother } \\
\text { Born } \\
\text { Slave } \\
\text { (std error) }\end{array}$ & $\begin{array}{r}\text { Mean if } \\
\text { Grandma } \\
\text { slave } \\
\text { sd(.) } \\
\mathrm{N}(.)\end{array}$ & $\begin{array}{r}\text { Mean if } \\
\text { Mom free } \\
\text { sd(.) } \\
\mathrm{N}(.)\end{array}$ \\
\hline $\begin{array}{l}\text { all black children in } \\
\text { sample ages } 0-15\end{array}$ & none & $\begin{array}{r}.065 \\
(.032)\end{array}$ & $\begin{array}{r}.154 \\
(.361) \\
13,860\end{array}$ & $\begin{array}{r}.089 \\
(.286) \\
258\end{array}$ \\
\hline $\begin{array}{l}\text { all black children in } \\
\text { sample ages } 0-15\end{array}$ & $\begin{array}{l}\text { birth year, region, } \\
\text { male, number sibs }\end{array}$ & $\begin{array}{r}.084 \\
(.035)\end{array}$ & $\begin{array}{r}.154 \\
(.361) \\
13,860\end{array}$ & $\begin{array}{r}.089 \\
(.286) \\
258\end{array}$ \\
\hline $\begin{array}{l}\text { black children outside } \\
\text { of South ages } 0-15\end{array}$ & $\begin{array}{l}\text { birth year, male, } \\
\text { number of siblings }\end{array}$ & $\begin{array}{r}.055 \\
(.043)\end{array}$ & $\begin{array}{r}.159 \\
(.366) \\
828\end{array}$ & $\begin{array}{r}.098 \\
(.297) \\
205\end{array}$ \\
\hline $\begin{array}{l}\text { black children in } \\
\text { South ages } 0-15\end{array}$ & $\begin{array}{l}\text { birth year, male, } \\
\text { number of siblings }\end{array}$ & $\begin{array}{l}.128 \\
(.054)\end{array}$ & $\begin{array}{r}.153 \\
(.361) \\
13,032\end{array}$ & $\begin{array}{r}.057 \\
(.233) \\
53\end{array}$ \\
\hline
\end{tabular}

Notes: 1880 sample includes black children ages 0-15 in IPUMS sample and in 100 percent sample. Mother's former slave status is imputed from year and state of birth. All of the mothers are born before 1865 and all of the children are born after 1865.1920 sample includes children ages 0-15 in IPUMS sample.

Female headed household are those with a woman listed as the head of household (and no spouse of the head listed within the household.) 


\section{Table V}

\section{Effect of Self or Mother Born Slave on Occupational Income Score, Probability of Being a Manual Laborer \\ (Male Household Heads in 1880 and 1920)}

This table compares occupational outcomes for black male heads of household who were former slaves (or whose mothers were former slaves) to outcomes for black male heads of household born free (or with mothers born free). "Effects" of slave status are calculated by using an OLS regression of the outcomes on former slave status.

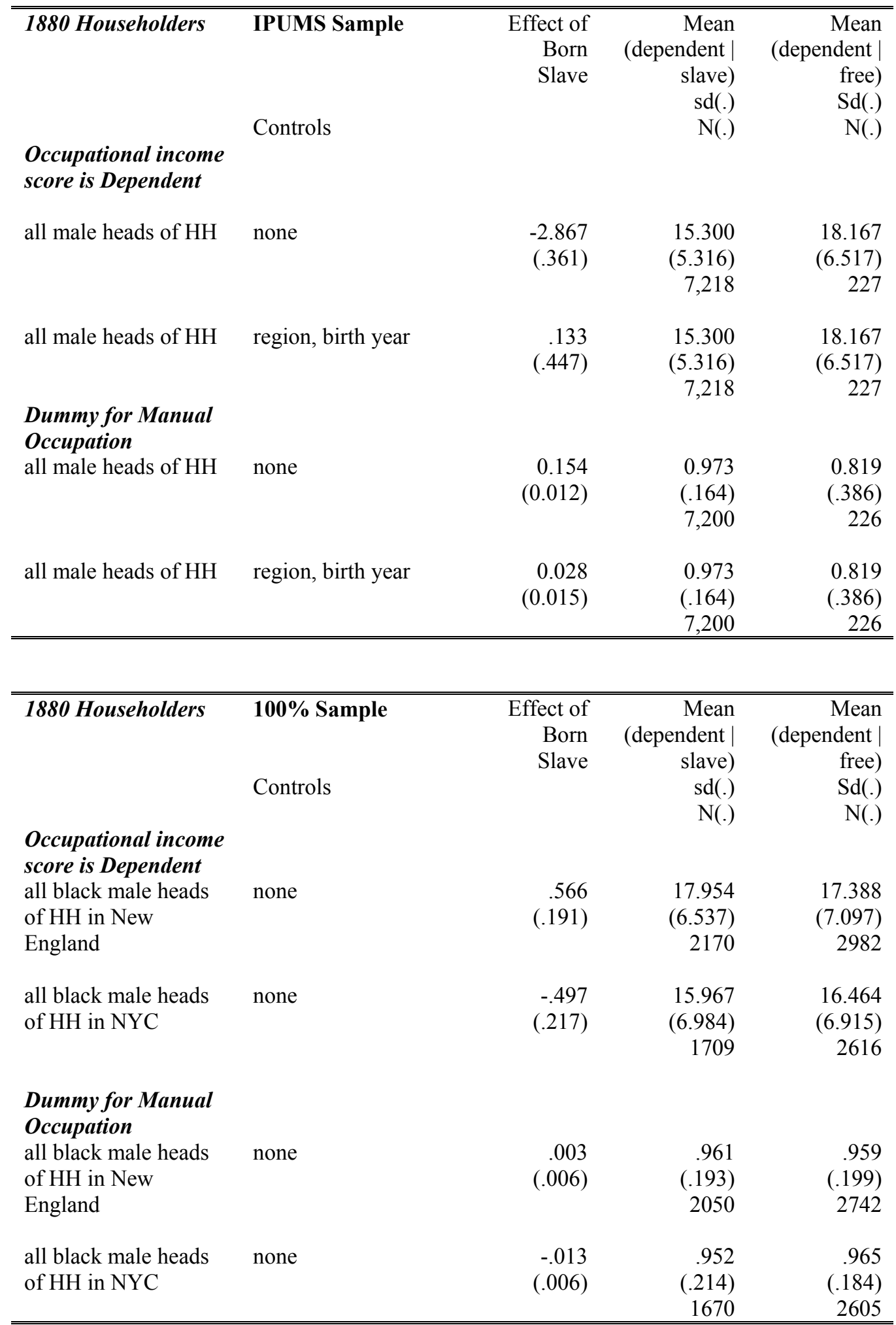




\begin{tabular}{|c|c|c|c|c|}
\hline Effect of Mother Born & $\begin{array}{c}\text { Table } \\
\text { Slave on Occ }\end{array}$ & $\begin{array}{l}\text { ontinued) } \\
\text { tional Inc }\end{array}$ & ne Score & lanual $\mathrm{V}$ \\
\hline 1920 Householders & & $\begin{array}{r}\text { Effect of } \\
\text { Mother Born } \\
\text { Slave } \\
\text { (std error) }\end{array}$ & $\begin{array}{r}\text { Mean if } \\
\text { Mom slave } \\
\text { sd(.) } \\
\mathrm{N}(.)\end{array}$ & $\begin{array}{r}\text { Mean if } \\
\text { Mom free } \\
\text { sd(.) } \\
\mathrm{N}(.)\end{array}$ \\
\hline $\begin{array}{l}\text { Occupational income } \\
\text { score } \\
\text { black male heads of } \\
\text { household, ages } 35-55\end{array}$ & $\begin{array}{l}\text { birth year, region, } \\
\text { number children }\end{array}$ & $\begin{array}{r}-.768 \\
(.619)\end{array}$ & $\begin{array}{r}17.119 \\
(6.517) \\
5,936\end{array}$ & $\begin{array}{r}21.709 \\
(7.774) \\
172\end{array}$ \\
\hline $\begin{array}{l}\text { Manual Laborer } \\
(0-1)\end{array}$ & & & & \\
\hline $\begin{array}{l}\text { black male heads of } \\
\text { household, ages 35-55 }\end{array}$ & $\begin{array}{l}\text { birth year, region, } \\
\text { number children }\end{array}$ & $\begin{array}{r}.063 \\
(.034)\end{array}$ & $\begin{array}{r}.931 \\
(.253) \\
5,896\end{array}$ & $\begin{array}{r}.762 \\
(.427) \\
172\end{array}$ \\
\hline
\end{tabular}

Notes: Samples include all black male heads of household. In the 1920 sample, the householders are ages 35-55 in 1920 (ie born 1865-1885) which makes them old enough to have parents who were born as slaves, but young enough to be born post-1865. In the 1880 sample, the householders are all born before 1865 .

Former slave status is imputed from year and state of birth. Those blacks born in one of 16 slave states prior to 1865 are coded as former slaves. (The count of 16 states includes West Virginia.) . For the 1920 data, if the householder's mother was born in one of 16 slave states, the mothers are coded as former slaves. There are four regional dummies coded such that the "South" dummy is really a slave states dummy. Missouri is coded as "South" and Washington, DC is not.

The occupational income score is the median 1950 annual income in hundreds of dollars for a given occupation Manual versus non-manual status is designated by the author based on job title. 


\section{Table VI \\ Means of Literacy, In School, Manual Occupation (0-1) \\ By Race and Slave-State Versus Not}

These panels are series of two by two matrices used to generate a simple estimate of the effect of being born into slavery on literacy, "in school" status, and occupation. The lower right hand cell of each panel is the black-white difference in means for individuals born outside the South minus the black white difference in means for individuals born in the South.

Panel A: Effect of Own Slavery Status on Own Literacy for Female Householders in 1880

\begin{tabular}{|c|c|c|c|c|}
\hline \multicolumn{5}{|c|}{ Mother's Literacy 1880} \\
\hline \multirow{6}{*}{ Born in slave state } & & Black & & Black/ \\
\hline & & 0 & 1 & white diff \\
\hline & 0 & 0.942 & 0.656 & -0.286 \\
\hline & & 30,531 & 317 & \\
\hline & 1 & 0.785 & 0.193 & -0.592 \\
\hline & & 18,214 & 8,622 & \\
\hline Slave state & & -0.157 & -0.463 & -0.306 \\
\hline
\end{tabular}

Panel B: Effect of Mother's Slavery Status on Child's Literacy Status in 1880

Child's Literacy 1880

Mother born in slave state
Black

0
Black/

1 white diff

0

$\begin{array}{rr}0.951 & 0.888 \\ 20,332 & 205\end{array}$

1

$0.702 \quad 0.339$

$14,420 \quad 7,237$

$-0.063$

$-0.363$
Slave state - Free State diff

$\begin{array}{ll}-0.249 & -0.549\end{array}$

$-0.300$

Panel C: Effect of Mother's Slavery Status on Literacy for Female Householders in 1920

\begin{tabular}{|c|c|c|c|}
\hline \multicolumn{4}{|l|}{$\begin{array}{l}\text { Female Household's } \\
\text { Literacy } 1920\end{array}$} \\
\hline mother born in slave state & $\begin{array}{r}\text { Black } \\
0\end{array}$ & 1 & $\begin{array}{r}\text { Black/ } \\
\text { white diff }\end{array}$ \\
\hline 0 & $\begin{array}{r}0.988 \\
31,311\end{array}$ & $\begin{array}{r}0.948 \\
326\end{array}$ & -0.040 \\
\hline 1 & $\begin{array}{r}0.945 \\
21,183\end{array}$ & $\begin{array}{l}0.659 \\
8,475\end{array}$ & -0.286 \\
\hline Slave state - Free State diff & -0.043 & -.289 & -0.246 \\
\hline
\end{tabular}




\section{Table VI (cont.)}

Panel D: Effect of Mother's Slavery Status on Literacy for Male Householders in 1920

\section{Male Householders literacy}

1920

mother born in slave state

$\begin{array}{rrr}\text { Black } & \text { Black/ } \\ 0 & 1 \quad \text { white diff }\end{array}$

0

$\begin{array}{rrr}0.986 & 0.851 & -0.135 \\ 26,745 & 289 & \\ & & \\ 0.929 & 0.667 & -0.262 \\ 18,075 & 6,270 & \end{array}$

Slave state - Free State diff

$-0.057$

$-0.184$

$-0.127$

Panel E: Effect of Grandmother's Slavery Status on Literacy for Children in 1920

\begin{tabular}{lrrrr}
\hline Child's Literacy 1920 & & & \\
& & Black & & $\begin{array}{r}\text { Black/ } \\
\text { white diff }\end{array}$ \\
Grandmother born in slave state & & & & \\
& 0 & 0.994 & 0.986 & -0.008 \\
& & 43,301 & 282 & \\
& 1 & 0.970 & 0.831 & -0.139 \\
& & 41,412 & 13,517 & \\
Slave state - Free State diff & -0.024 & -0.155 & -0.131 \\
\hline \hline
\end{tabular}

Panel F: Effect of mother's Slavery Status on Schooling Status for Children in 1880

Child is In School 1880

Mother born in slave state

$\begin{array}{rrr}\text { Black } & \text { Black/ } \\ 0 & 1 \quad \text { white diff }\end{array}$

$\begin{array}{rrrr}0 & 0.832 & 0.669 & -0.163 \\ & 32,213 & 317 & \\ & & & \\ 1 & 0.597 & 0.309 & -0.288 \\ & 23,357 & 12,025 & \end{array}$

Slave state - Free State diff

$-0.235-0.360$

$-0.125$ 
Panel G: Effect of Grandmother's Slavery Status on Schooling Status for Children in 1920

Child is In School 1920

Grandmother born in slave state

Black

Black/

Grandmother born in slave state

0

$\begin{array}{rrr}0.817 & 0.758 & -0.059 \\ 38,682 & 248 & \end{array}$

1

$0.795 \quad 0.664$

$-0.131$

$39,140 \quad 12,871$

Slave state - Free State diff

$-0.022$

$-0.094$

$-0.072$

Panel H: Effect of Own Slavery Status on Manual for Male Householders in 1880

Father is Manual Worker

1880

\begin{tabular}{lrrrr} 
Father born in slave state & Black & & $\begin{array}{r}\text { Black/ } \\
\text { white diff }\end{array}$ \\
& 0 & 1 & \\
& & 0.818 & 0.819 & 0.001 \\
& 26,306 & 226 & \\
1 & 0.892 & 0.973 & 0.081 \\
& 15,970 & 7,200 & \\
Slave state - Free State diff & 0.074 & 0.154 & 0.080 \\
\hline \hline
\end{tabular}

Panel I: Effect of Mother's Slavery Status on Manual for Male Householders in 1920

\section{Father Has Manual \\ Occupation 1920}

Father's mother born in slave state

\section{Black}

0
Black/

1 white diff

$\begin{array}{rrrr}0 & 0.684 & 0.814 & 0.130 \\ & 25,650 & 279 & \\ & & & \\ 1 & 0.772 & 0.931 & 0.159 \\ & 17,507 & 6,137 & \end{array}$

Slave state - Free State diff

$0.088 \quad 0.117$

0.029 


\section{Table VII \\ Outcomes for Heads of Household and Spouses in 1880 Census By Own Race and Birth Place}

This table uses OLS to estimate the "effect" on adult outcomes of being born a slave. The estimated effect is simply the interaction between being black and being born in a slave state. The regressions include whites and blacks born pre-1865 in slave and non-slave states. The regressions include the main effects of being black, being born in the South (slave states), and the interaction between the two.

\begin{tabular}{|c|c|c|c|c|c|c|c|c|}
\hline & (1) & (2) & (3) & (4) & (5) & (6) & (7) & (8) \\
\hline & $\begin{array}{l}\text { Literacy } \\
\text { Women }\end{array}$ & $\begin{array}{l}\text { Literacy } \\
\text { Women }\end{array}$ & $\begin{array}{r}\text { Literacy } \\
\text { Men }\end{array}$ & $\begin{array}{r}\text { Literacy } \\
\text { Men }\end{array}$ & $\begin{array}{r}\text { Occupati } \\
\text { onal } \\
\text { income } \\
\text { score }\end{array}$ & $\begin{array}{r}\text { Occupati } \\
\text { onal } \\
\text { income } \\
\text { score }\end{array}$ & $\begin{array}{r}\text { Manual } \\
\text { worker } \\
(0-1)\end{array}$ & $\begin{array}{r}\text { Manual } \\
\text { worker } \\
(0-1)\end{array}$ \\
\hline $\begin{array}{l}\text { Black* } \\
\text { born slave state }\end{array}$ & $\begin{array}{r}-0.307 \\
(0.019)\end{array}$ & $\begin{array}{r}-0.302 \\
(0.019)\end{array}$ & $\begin{array}{r}-0.338 \\
(0.021)\end{array}$ & $\begin{array}{r}-0.334 \\
(0.021)\end{array}$ & $\begin{array}{r}0.669 \\
(0.711)\end{array}$ & $\begin{array}{r}1.062 \\
(0.705)\end{array}$ & $\begin{array}{r}0.080 \\
(0.023)\end{array}$ & $\begin{array}{r}0.072 \\
(0.023)\end{array}$ \\
\hline $\begin{array}{l}\text { Born in slave state } \\
\text { (self) }\end{array}$ & $\begin{array}{r}-0.156 \\
(0.003)\end{array}$ & $\begin{array}{r}-0.063 \\
(0.005)\end{array}$ & $\begin{array}{r}-0.128 \\
(0.003)\end{array}$ & $\begin{array}{r}-0.048 \\
(0.005)\end{array}$ & $\begin{array}{r}-3.536 \\
(0.104)\end{array}$ & $\begin{array}{r}-1.465 \\
(0.180)\end{array}$ & $\begin{array}{r}0.074 \\
(0.003)\end{array}$ & $\begin{array}{r}0.021 \\
(0.006)\end{array}$ \\
\hline Black & $\begin{array}{r}-0.285 \\
(0.018)\end{array}$ & $\begin{array}{r}-0.283 \\
(0.018)\end{array}$ & $\begin{array}{l}-0.250 \\
(0.021)\end{array}$ & $\begin{array}{r}-0.243 \\
(0.020)\end{array}$ & $\begin{array}{r}-3.584 \\
(0.695)\end{array}$ & $\begin{array}{r}-3.839 \\
(0.690)\end{array}$ & $\begin{array}{r}0.001 \\
(0.023)\end{array}$ & $\begin{array}{r}0.002 \\
(0.023)\end{array}$ \\
\hline $\begin{array}{l}\text { Number of own } \\
\text { Children in house }\end{array}$ & & $\begin{array}{r}0.012 \\
(0.006)\end{array}$ & & $\begin{array}{r}0.018 \\
(0.006)\end{array}$ & & $\begin{array}{r}0.722 \\
(0.202)\end{array}$ & & $\begin{array}{l}-0.020 \\
(0.007)\end{array}$ \\
\hline $\begin{array}{l}\text { South is } \\
\text { Current region }\end{array}$ & & $\begin{array}{r}-0.002 \\
(0.010)\end{array}$ & & $\begin{array}{r}-0.017 \\
(0.010)\end{array}$ & & $\begin{array}{r}-2.054 \\
(0.333)\end{array}$ & & $\begin{array}{r}0.059 \\
(0.011)\end{array}$ \\
\hline $\begin{array}{l}\text { Central is } \\
\text { Current region }\end{array}$ & & $\begin{array}{r}0.104 \\
(0.009)\end{array}$ & & $\begin{array}{r}0.069 \\
(0.009)\end{array}$ & & $\begin{array}{r}-1.281 \\
(0.313)\end{array}$ & & $\begin{array}{r}0.026 \\
(0.010)\end{array}$ \\
\hline $\begin{array}{l}\text { Northeast is } \\
\text { current region }\end{array}$ & & $\begin{array}{r}0.120 \\
(0.009)\end{array}$ & & $\begin{array}{r}0.089 \\
(0.009)\end{array}$ & & $\begin{array}{r}1.593 \\
(0.315)\end{array}$ & & $\begin{array}{r}-0.023 \\
(0.010)\end{array}$ \\
\hline Constant & $\begin{array}{r}0.942 \\
(0.002)\end{array}$ & $\begin{array}{r}0.838 \\
(0.009)\end{array}$ & $\begin{array}{r}0.953 \\
(0.002)\end{array}$ & $\begin{array}{r}0.879 \\
(0.009)\end{array}$ & $\begin{array}{r}21.751 \\
(0.064)\end{array}$ & $\begin{array}{r}21.599 \\
(0.303)\end{array}$ & $\begin{array}{r}0.818 \\
(0.002)\end{array}$ & $\begin{array}{r}0.816 \\
(0.010)\end{array}$ \\
\hline $\begin{array}{l}\text { Observations } \\
\text { R-squared }\end{array}$ & $\begin{array}{r}57684 \\
0.38\end{array}$ & $\begin{array}{r}57684 \\
0.39\end{array}$ & $\begin{array}{r}51104 \\
0.38\end{array}$ & $\begin{array}{r}51104 \\
0.38\end{array}$ & $\begin{array}{r}49952 \\
0.05\end{array}$ & $\begin{array}{r}49952 \\
0.07\end{array}$ & $\begin{array}{r}49702 \\
0.03\end{array}$ & $\begin{array}{r}49702 \\
0.04\end{array}$ \\
\hline
\end{tabular}

Men refers to a male head of household. "Women" refers to a spouse of a male head of household or a female head of household. All are born pre-1865. Standard errors in parentheses. All columns use OLS. Columns (5)-(8) are for male heads of household only. Literacy and manual worker are (0-1) dummies. 


\section{Table VIII \\ Outcomes for Children in 1880 Census \\ By Race and Birthplace of Mother}

This table uses OLS to estimate the "effect" on child outcomes of having a mother who was born a slave. The estimated effect is simply the interaction between being black and mother born in a slave state. The regressions include whites and blacks born pre-1865 in slave and non-slave states. The regressions include the main effects of being black, mother born in the South (slave states), and the interaction between the two.

\begin{tabular}{|c|c|c|c|c|}
\hline & (1) & (2) & (3) & (4) \\
\hline & Literate & Literate & In School & In School \\
\hline $\begin{array}{l}\text { Black*Mother } \\
\text { born in slave state }\end{array}$ & $\begin{array}{r}-0.299 \\
(0.029)\end{array}$ & $\begin{array}{r}-0.290 \\
(0.027)\end{array}$ & $\begin{array}{r}-0.125 \\
(0.036)\end{array}$ & $\begin{array}{r}-0.119 \\
(0.034)\end{array}$ \\
\hline $\begin{array}{l}\text { Mother born } \\
\text { in slave state }\end{array}$ & $\begin{array}{r}-0.250 \\
(0.005)\end{array}$ & $\begin{array}{r}-0.060 \\
(0.008)\end{array}$ & $\begin{array}{r}-0.235 \\
(0.005)\end{array}$ & $\begin{array}{r}-0.054 \\
(0.009)\end{array}$ \\
\hline Black & $\begin{array}{r}-0.064 \\
(0.028)\end{array}$ & $\begin{array}{r}-0.058 \\
(0.026)\end{array}$ & $\begin{array}{r}-0.163 \\
(0.035)\end{array}$ & $\begin{array}{r}-0.152 \\
(0.033)\end{array}$ \\
\hline Male & & $\begin{array}{r}-0.026 \\
(0.004)\end{array}$ & & $\begin{array}{r}-0.009 \\
(0.003)\end{array}$ \\
\hline $\begin{array}{l}\text { Number of own } \\
\text { siblings in } \\
\text { household }\end{array}$ & & $\begin{array}{r}-0.012 \\
(0.001)\end{array}$ & & $\begin{array}{r}0.000 \\
(0.001)\end{array}$ \\
\hline $\begin{array}{l}\text { South is } \\
\text { current region }\end{array}$ & & $\begin{array}{r}-0.113 \\
(0.016)\end{array}$ & & $\begin{array}{r}-0.054 \\
(0.018)\end{array}$ \\
\hline $\begin{array}{l}\text { Central is } \\
\text { current region }\end{array}$ & & $\begin{array}{r}0.102 \\
(0.016)\end{array}$ & & $\begin{array}{r}0.162 \\
(0.017)\end{array}$ \\
\hline $\begin{array}{l}\text { Northeast } \\
\text { is current region }\end{array}$ & & $\begin{array}{r}0.111 \\
(0.016)\end{array}$ & & $\begin{array}{r}0.172 \\
(0.017)\end{array}$ \\
\hline Constant & $\begin{array}{r}0.951 \\
(0.002)\end{array}$ & $\begin{array}{r}0.915 \\
(0.016)\end{array}$ & $\begin{array}{r}0.832 \\
(0.003)\end{array}$ & $\begin{array}{r}0.687 \\
(0.017)\end{array}$ \\
\hline $\begin{array}{l}\text { Observations } \\
\text { R-squared }\end{array}$ & $\begin{array}{r}42,194 \\
0.27\end{array}$ & $\begin{array}{r}42,194 \\
0.30\end{array}$ & $\begin{array}{r}67,912 \\
0.17\end{array}$ & $\begin{array}{r}67,912 \\
0.20\end{array}$ \\
\hline
\end{tabular}

Robust standard errors in parentheses. Standard errors are clustered at the household level. Literacy is measured for children 9 or older. "In school" is measured for children 7-18. All children are born after 1865. All parents are born before 1865. 


\section{Table IX \\ Outcomes for Heads of Household and Spouses in 1920 Census By Race and Birth Place of Their Mother}

This table uses OLS to estimate the "effect" on adult outcomes of having a mother who was born a slave. The estimated effect is simply the interaction between being black and mother born in a slave state. The regressions include whites and blacks born pre-1865 in slave and non-slave states. The regressions include the main effects of being black, mother born in the South (slave states), and the interaction between the two.

\begin{tabular}{|c|c|c|c|c|c|c|c|c|}
\hline & (1) & (2) & (3) & (4) & (5) & (6) & (7) & (8) \\
\hline & $\begin{array}{l}\text { Literate } \\
\text { Women }\end{array}$ & $\begin{array}{l}\text { Literate } \\
\text { Women }\end{array}$ & $\begin{array}{r}\text { Literate } \\
\text { Men }\end{array}$ & $\begin{array}{r}\text { Literate } \\
\text { Men }\end{array}$ & $\begin{array}{r}\text { Occupati } \\
\text { onal } \\
\text { income } \\
\text { score }\end{array}$ & $\begin{array}{r}\text { Occupati } \\
\text { onal } \\
\text { income } \\
\text { score }\end{array}$ & $\begin{array}{r}\text { Manual } \\
\text { worker } \\
(0-1)\end{array}$ & $\begin{array}{r}\text { Manual } \\
\text { worker } \\
(0-1)\end{array}$ \\
\hline $\begin{array}{l}\text { Black*mother } \\
\text { born slave state }\end{array}$ & $\begin{array}{r}-0.246 \\
(0.013)\end{array}$ & $\begin{array}{r}-0.245 \\
(0.013)\end{array}$ & $\begin{array}{r}-0.127 \\
(0.015)\end{array}$ & $\begin{array}{r}-0.161 \\
(0.015)\end{array}$ & $\begin{array}{r}0.786 \\
(0.720)\end{array}$ & $\begin{array}{r}-0.385 \\
(0.731)\end{array}$ & $\begin{array}{r}0.029 \\
(0.027)\end{array}$ & $\begin{array}{r}0.074 \\
(0.027)\end{array}$ \\
\hline $\begin{array}{l}\text { Mother born } \\
\text { in slave state }\end{array}$ & $\begin{array}{r}-0.043 \\
(0.002)\end{array}$ & $\begin{array}{r}0.013 \\
(0.003)\end{array}$ & $\begin{array}{r}-0.057 \\
(0.002)\end{array}$ & $\begin{array}{r}-0.002 \\
(0.003)\end{array}$ & $\begin{array}{r}-3.954 \\
(0.114)\end{array}$ & $\begin{array}{r}-1.462 \\
(0.169)\end{array}$ & $\begin{array}{r}0.088 \\
(0.004)\end{array}$ & $\begin{array}{r}0.041 \\
(0.006)\end{array}$ \\
\hline Black & $\begin{array}{r}-0.040 \\
(0.013)\end{array}$ & $\begin{array}{r}-0.039 \\
(0.013)\end{array}$ & $\begin{array}{r}-0.135 \\
(0.014)\end{array}$ & $\begin{array}{r}-0.096 \\
(0.015)\end{array}$ & $\begin{array}{r}-5.996 \\
(0.699)\end{array}$ & $\begin{array}{r}-4.776 \\
(0.711)\end{array}$ & $\begin{array}{r}0.130 \\
(0.026)\end{array}$ & $\begin{array}{r}0.083 \\
(0.026)\end{array}$ \\
\hline $\begin{array}{l}\text { Number of own } \\
\text { siblings in house }\end{array}$ & & $\begin{array}{r}0.008 \\
(0.004)\end{array}$ & & $\begin{array}{r}0.015 \\
(0.008)\end{array}$ & & $\begin{array}{r}1.187 \\
(0.373)\end{array}$ & & $\begin{array}{r}-0.031 \\
(0.014)\end{array}$ \\
\hline $\begin{array}{l}\text { South is } \\
\text { current region }\end{array}$ & & $\begin{array}{r}-0.039 \\
(0.004)\end{array}$ & & $\begin{array}{r}-0.052 \\
(0.005)\end{array}$ & & $\begin{array}{r}-2.520 \\
(0.234)\end{array}$ & & $\begin{array}{r}0.072 \\
(0.009)\end{array}$ \\
\hline $\begin{array}{l}\text { Central is } \\
\text { current region }\end{array}$ & & $\begin{array}{r}0.035 \\
(0.004)\end{array}$ & & $\begin{array}{r}0.018 \\
(0.004)\end{array}$ & & $\begin{array}{r}-0.787 \\
(0.219)\end{array}$ & & $\begin{array}{r}0.042 \\
(0.008)\end{array}$ \\
\hline $\begin{array}{l}\text { Northeast is } \\
\text { current region }\end{array}$ & & $\begin{array}{r}0.042 \\
(0.004)\end{array}$ & & $\begin{array}{r}0.022 \\
(0.005)\end{array}$ & & $\begin{array}{r}2.233 \\
(0.224)\end{array}$ & & $\begin{array}{r}-0.019 \\
(0.008)\end{array}$ \\
\hline Constant & $\begin{array}{r}0.988 \\
(0.001)\end{array}$ & $\begin{array}{r}0.960 \\
(0.003)\end{array}$ & $\begin{array}{r}0.986 \\
(0.001)\end{array}$ & $\begin{array}{r}0.972 \\
(0.004)\end{array}$ & $\begin{array}{r}26.315 \\
(0.072)\end{array}$ & $\begin{array}{l}25.925 \\
(0.197)\end{array}$ & $\begin{array}{r}0.684 \\
(0.003)\end{array}$ & $\begin{array}{r}0.668 \\
(0.007)\end{array}$ \\
\hline Observations & 61295 & 61295 & 51379 & 51379 & 50068 & 50068 & 49573 & 49573 \\
\hline R-squared & 0.18 & 0.19 & 0.15 & 0.17 & 0.07 & 0.08 & 0.03 & 0.04 \\
\hline
\end{tabular}

Standard errors in parentheses. 


\section{Table X \\ Outcomes for Children in 1920 Census \\ By Race and BirthPlace of Grandmother}

This table uses OLS to estimate the effect on grandchild outcomes of having a grandmother who is born a slave. The estimated effect is simply the interaction between being black and grandmother born in a slave state. The regressions include whites and blacks born pre-1865 in slave and non-slave states. The regressions include the main effects of being black, grandmother born in the South (slave states), and the interaction between the two.

\begin{tabular}{lrrrr}
\hline \hline & $(1)$ & $(2)$ & $(3)$ & $(4)$ \\
& Literate & Literate & In School & In School \\
& -0.131 & -0.131 & -0.072 & -0.090 \\
Black*Grandma & $(0.010)$ & $(0.010)$ & $(0.037)$ & $(0.033)$ \\
born in slave state & & & -0.022 & -0.002 \\
& -0.024 & 0.006 & $(0.003)$ & $(0.005)$ \\
Grandmother born & $(0.001)$ & $(0.001)$ & -0.059 & -0.034 \\
in slave state & & & $(0.036)$ & $(0.033)$ \\
Black & -0.009 & -0.007 & & -0.031 \\
& $(0.009)$ & $(0.008)$ & & $(0.002)$ \\
Male & & -0.015 & & -0.008 \\
& & $(0.001)$ & & $(0.001)$ \\
Number of own & & -0.003 & & -0.048 \\
siblings in & & $(0.000)$ & & $(0.006)$ \\
household & & -0.021 & & -0.017 \\
South is \\
current region
\end{tabular}

Robust standard errors in parentheses. Standard errors are corrected for clustering at the family level. 


\section{Table XI \\ Transmission of Literacy and Occupational Income Score From Parents to Children: 1880 Census}

This table shows the connection between child literacy (income score) and parent literacy and income score. The transmission rates for both outcomes are stronger for blacks than for whites. All children are born post-1865 and parents are born pre-1865. Children in households are ages 0-35. Transmission rate is estimated by regression child outcome on parent outcome.

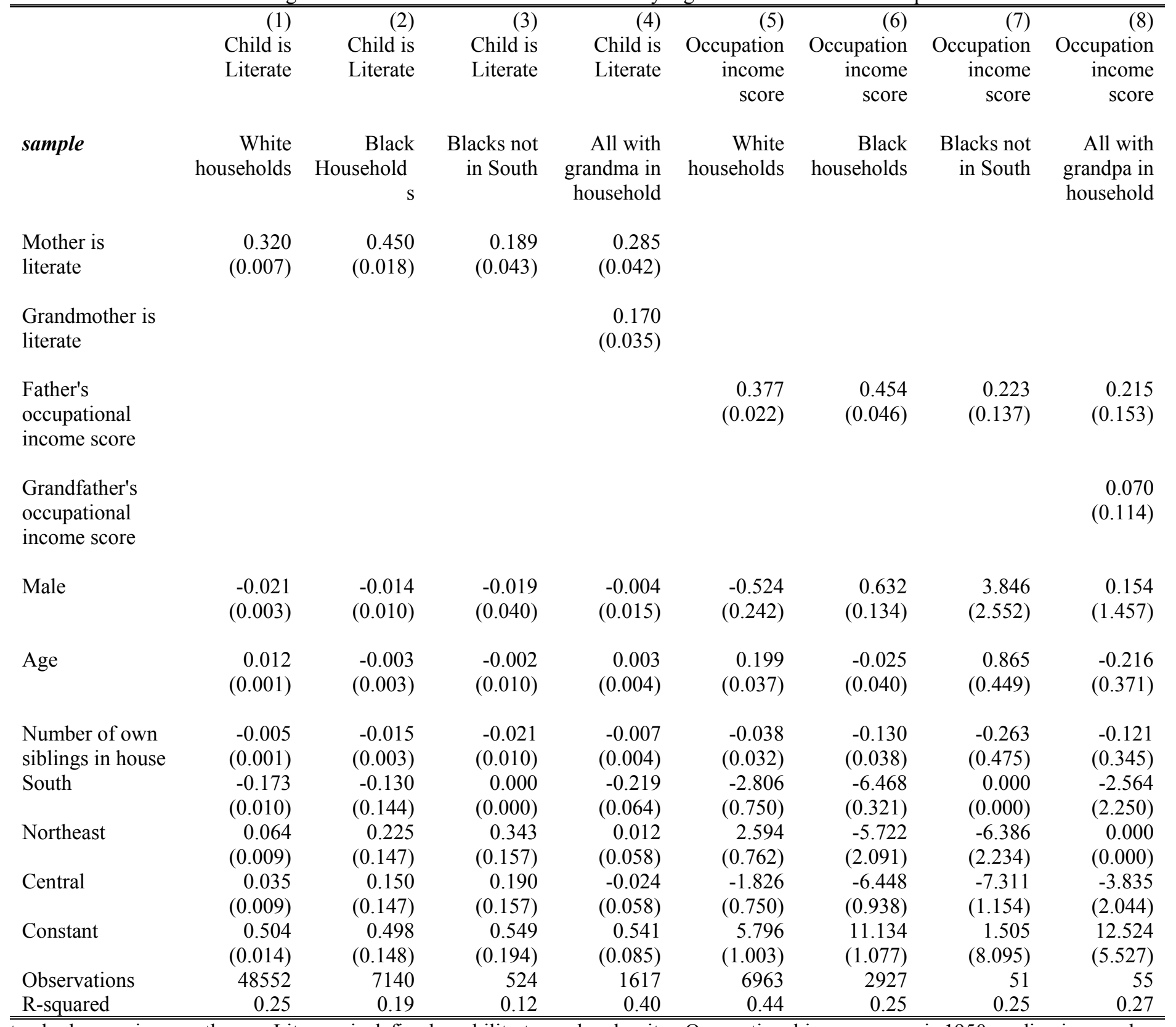

Robust standard errors in parentheses. Literacy is defined as ability to read and write. Occupational income score is 1950 median income by occupatio in hundreds of 1950 dollars. (This variable is created by the IPUMS researchers.) Grandmother's literacy is mother's mother's literacy. It is onl. available in cases where the grandmother lives in the household. Grandfather's occupational score is that of father's father. It is only available if th father's father lives in the household AND has an occupation listed. 


\section{Table XII \\ Transmission of Literacy and Occupational Income Score From Parents to Children: 1920 Census}

This table shows the connection between child literacy (income score) and parent literacy and income score. The transmission coefficients for both outcomes are stronger for blacks than for whites. Children in households are ages 7-35.

\begin{tabular}{|c|c|c|c|c|c|c|c|c|}
\hline & $\begin{array}{r}\text { (1) } \\
\text { Child is } \\
\text { Literate }\end{array}$ & $\begin{array}{r}\text { (2) } \\
\text { Child is } \\
\text { Literate }\end{array}$ & $\begin{array}{r}\text { (3) } \\
\text { Child is } \\
\text { Literate }\end{array}$ & $\begin{array}{r}(4) \\
\text { Literate }\end{array}$ & $\begin{array}{r}(5) \\
\text { Occupation } \\
\text { income score }\end{array}$ & $\begin{array}{r}(6) \\
\text { Occupation } \\
\text { income score }\end{array}$ & $\begin{array}{r}(7) \\
\text { Occupation } \\
\text { income score }\end{array}$ & $\begin{array}{r}(8) \\
\text { Occupation } \\
\text { income score }\end{array}$ \\
\hline sample & $\begin{array}{r}\text { White } \\
\text { households }\end{array}$ & $\begin{array}{r}\text { Black } \\
\text { households }\end{array}$ & $\begin{array}{r}\text { Blacks not in } \\
\text { South }\end{array}$ & $\begin{array}{r}\text { All with } \\
\text { grandma in } \\
\text { household }\end{array}$ & $\begin{array}{r}\text { White } \\
\text { households }\end{array}$ & $\begin{array}{r}\text { Black } \\
\text { households }\end{array}$ & $\begin{array}{r}\text { Blacks not in } \\
\text { South }\end{array}$ & $\begin{array}{r}\text { All with } \\
\text { grandpa in } \\
\text { household }\end{array}$ \\
\hline Mother is literate & $\begin{array}{r}0.090 \\
(0.004)\end{array}$ & $\begin{array}{r}0.239 \\
(0.011)\end{array}$ & $\begin{array}{r}0.030 \\
(0.024)\end{array}$ & $\begin{array}{r}0.177 \\
(0.037)\end{array}$ & & & & \\
\hline $\begin{array}{l}\text { Grandmother is } \\
\text { literate }\end{array}$ & & & & $\begin{array}{r}0.043 \\
(0.013)\end{array}$ & & & & \\
\hline $\begin{array}{l}\text { Father's } \\
\text { occupational } \\
\text { income score }\end{array}$ & & & & & $\begin{array}{r}0.403 \\
(0.005)\end{array}$ & $\begin{array}{r}0.550 \\
(0.031)\end{array}$ & $\begin{array}{r}0.190 \\
(0.067)\end{array}$ & $\begin{array}{r}0.425 \\
(0.111)\end{array}$ \\
\hline $\begin{array}{l}\text { Grandfather's } \\
\text { occupational } \\
\text { income score }\end{array}$ & & & & & & & & $\begin{array}{r}0.073 \\
(0.104)\end{array}$ \\
\hline Male & $\begin{array}{l}-0.005 \\
(0.001)\end{array}$ & $\begin{array}{r}-0.051 \\
(0.006)\end{array}$ & $\begin{array}{l}-0.008 \\
(0.007)\end{array}$ & $\begin{array}{l}-0.016 \\
(0.005)\end{array}$ & $\begin{array}{l}-0.215 \\
(0.075)\end{array}$ & $\begin{array}{r}2.772 \\
(0.191)\end{array}$ & $\begin{array}{r}7.247 \\
(0.856)\end{array}$ & $\begin{array}{r}-1.041 \\
(1.525)\end{array}$ \\
\hline Age & $\begin{array}{l}-0.000 \\
(0.000)\end{array}$ & $\begin{array}{r}0.005 \\
(0.001)\end{array}$ & $\begin{array}{r}0.000 \\
(0.001)\end{array}$ & $\begin{array}{r}0.001 \\
(0.001)\end{array}$ & $\begin{array}{r}0.354 \\
(0.009)\end{array}$ & $\begin{array}{r}0.349 \\
(0.023)\end{array}$ & $\begin{array}{r}0.127 \\
(0.089)\end{array}$ & $\begin{array}{r}0.746 \\
(0.347)\end{array}$ \\
\hline $\begin{array}{l}\text { Number of own } \\
\text { Siblings in house }\end{array}$ & $\begin{array}{l}-0.000 \\
(0.000)\end{array}$ & $\begin{array}{r}-0.009 \\
(0.002)\end{array}$ & $\begin{array}{l}-0.001 \\
(0.001)\end{array}$ & $\begin{array}{l}-0.000 \\
(0.002)\end{array}$ & $\begin{array}{l}-0.239 \\
(0.019)\end{array}$ & $\begin{array}{l}-0.199 \\
(0.044)\end{array}$ & $\begin{array}{r}0.124 \\
(0.177)\end{array}$ & $\begin{array}{r}0.899 \\
(0.392)\end{array}$ \\
\hline South & $\begin{array}{l}-0.022 \\
(0.002)\end{array}$ & $\begin{array}{r}-0.091 \\
(0.011)\end{array}$ & $\begin{array}{r}0.000 \\
(0.000)\end{array}$ & $\begin{array}{l}-0.047 \\
(0.010)\end{array}$ & $\begin{array}{l}-2.911 \\
(0.195)\end{array}$ & $\begin{array}{l}-3.457 \\
(2.337)\end{array}$ & $\begin{array}{r}0.000 \\
(0.000)\end{array}$ & $\begin{array}{r}0.000 \\
(0.000)\end{array}$ \\
\hline Northeast & $\begin{array}{r}0.012 \\
(0.001)\end{array}$ & $\begin{array}{r}0.006 \\
(0.012)\end{array}$ & $\begin{array}{l}-0.008 \\
(0.005)\end{array}$ & $\begin{array}{l}-0.007 \\
(0.008)\end{array}$ & $\begin{array}{r}2.631 \\
(0.178)\end{array}$ & $\begin{array}{r}2.538 \\
(2.420)\end{array}$ & $\begin{array}{r}1.780 \\
(1.850)\end{array}$ & $\begin{array}{r}1.954 \\
(2.275)\end{array}$ \\
\hline Central & $\begin{array}{r}0.006 \\
(0.001)\end{array}$ & $\begin{array}{r}0.014 \\
(0.013)\end{array}$ & $\begin{array}{l}-0.007 \\
(0.005)\end{array}$ & $\begin{array}{l}-0.013 \\
(0.008)\end{array}$ & $\begin{array}{l}-0.082 \\
(0.184)\end{array}$ & $\begin{array}{r}0.916 \\
(2.384)\end{array}$ & $\begin{array}{r}0.152 \\
(1.825)\end{array}$ & $\begin{array}{r}4.009 \\
(2.285)\end{array}$ \\
\hline Constant & $\begin{array}{r}0.908 \\
(0.004)\end{array}$ & $\begin{array}{r}0.739 \\
(0.021)\end{array}$ & $\begin{array}{r}0.972 \\
(0.026)\end{array}$ & $\begin{array}{r}0.793 \\
(0.036)\end{array}$ & $\begin{array}{r}3.647 \\
(0.294)\end{array}$ & $\begin{array}{l}-3.520 \\
(2.459)\end{array}$ & $\begin{array}{r}5.078 \\
(3.108)\end{array}$ & $\begin{array}{r}-11.328 \\
(6.602)\end{array}$ \\
\hline Observations & 171973 & 13697 & 1278 & 3769 & 56522 & 5306 & 423 & 63 \\
\hline R-squared & 0.05 & 0.11 & 0.01 & 0.15 & 0.33 & 0.38 & 0.25 & 0.47 \\
\hline
\end{tabular}

Robust standard errors in parentheses. Literacy is defined as ability to read and write. Occupational income score is 1950 median income by occupatio in hundreds of 1950 dollars. (This variable is created by the IPUMS researchers.) Granmother's literacy is mother's mother's literacy. It is onl. available in cases where the grandmother lives in the household. Grandfather's occupational score is that of father's father. It is only available if th father's father lives in the household AND has an occupation listed. 


\section{Table XIII}

\section{Means from Sample of Families in Both 1880 Census and 1920 IPUMS Means By Matched and Unmatched Samples}

The data are from a sample that matches father's ages 40-60in the 1920 IPUMS back into the 1880 Census (when the fathers were ages 0-20). The match is done on first name, last name, year of birth, race, place of birth and mother and father's place of birth. The objective of the merge is to get some information on father's father's occupation and to create a sample with three generations of adults within each family.

\begin{tabular}{|c|c|c|c|c|c|c|c|}
\hline \multirow[b]{2}{*}{ Variable } & \multirow[b]{2}{*}{ Obs } & \multicolumn{2}{|l|}{ Matched } & \multicolumn{3}{|c|}{ Unmatched } & \multirow[b]{2}{*}{$\begin{array}{l}\mathrm{t} \text {-stat for } \\
\text { diff in } \\
\text { means }\end{array}$} \\
\hline & & Mean & Std. Dev. & Obs & Mean & Std. Dev. & \\
\hline \multicolumn{8}{|l|}{ Children } \\
\hline Literacy & 5,789 & 0.98 & 0.15 & 42,397 & 0.97 & 0.17 & 2.79 \\
\hline Occupational income score & 3,261 & 18.51 & 10.47 & 25,214 & 18.21 & 10.84 & 1.50 \\
\hline Manual worker & 3,209 & 0.74 & 0.44 & 24,951 & 0.74 & 0.44 & 0.30 \\
\hline Age & 7,126 & 15.97 & 6.96 & 50,033 & 17.42 & 7.49 & -15.4 \\
\hline Male & 7,126 & 0.62 & 0.49 & 50,033 & 0.63 & 0.48 & -2.05 \\
\hline Black & 7,126 & 0.14 & 0.35 & 50,033 & 0.10 & 0.30 & 9.24 \\
\hline Region=northeast & 7,126 & 0.27 & 0.45 & 50,033 & 0.19 & 0.40 & 15.94 \\
\hline Region=south & 7,126 & 0.37 & 0.48 & 50,033 & 0.44 & 0.50 & -10.20 \\
\hline Region $=$ central & 7,126 & 0.32 & 0.47 & 50,033 & 0.31 & 0.46 & 1.64 \\
\hline Region=west & 7,126 & 0.04 & 0.19 & 50,033 & 0.06 & 0.24 & -8.98 \\
\hline \multicolumn{8}{|l|}{ Fathers } \\
\hline Literacy & 1,854 & 0.94 & 0.23 & 14,384 & 0.92 & 0.26 & 2.77 \\
\hline Occupational income score & 1,854 & 22.57 & 10.28 & 14,382 & 22.43 & 11.02 & 0.51 \\
\hline Manual worker & 1,854 & 0.82 & 0.38 & 14,383 & 0.80 & 0.40 & 2.24 \\
\hline
\end{tabular}

Pre-merge sample is limited to father's in 1920 IPUMs who were born after the Civil War but prior to the 1880 Census. I further limit the sample to families that have at least one male child in the household who is 18 or more years of age. 


\section{Table XIV \\ Intergenerational Transmission of Occupational Income Score}

The data are from the merged sample of families described in the previous table. Families in the 1880 Census are merged with families in the 1920s IPUMs. Transmission coefficients are obtained by regressing child's income score on father's and grandfather's income score. Columns (3) and (6) show the transmission coefficients when we exclude households in which the father (1920 Head of Household) is a farmer or farm laborer.

\begin{tabular}{|c|c|c|c|c|c|c|}
\hline & \multicolumn{3}{|c|}{ Blacks } & \multicolumn{3}{|c|}{ Whites } \\
\hline & (1) & (2) & (3) & (4) & (5) & (6) \\
\hline & Son/ & Son/ & Son/ & Son/ & Son/ & Son/ \\
\hline & daughter's & daughter's & daughter's & daughter's & daughter's & daughter's \\
\hline & occupation & occupation & occupation & occupation & occupation & occupation \\
\hline & $\begin{array}{r}\text { al income } \\
\text { score }\end{array}$ & $\begin{array}{r}\text { al income } \\
\text { score }\end{array}$ & $\begin{array}{r}\text { al income } \\
\text { score }\end{array}$ & $\begin{array}{r}\text { al income } \\
\text { score }\end{array}$ & $\begin{array}{r}\text { al income } \\
\text { score }\end{array}$ & $\begin{array}{r}\text { al income } \\
\text { score }\end{array}$ \\
\hline & & & non- & & & non- \\
\hline & & & farmers & & & farmers \\
\hline \multirow{2}{*}{$\begin{array}{l}\text { Father's occupational income } \\
\text { score }\end{array}$} & 0.554 & & 0.198 & 0.525 & & 0.230 \\
\hline & $(0.128)$ & & $(0.122)$ & $(0.025)$ & & $(0.030)$ \\
\hline \multirow{2}{*}{$\begin{array}{l}\text { Grandfather's occupational } \\
\text { income score }\end{array}$} & 0.057 & -0.042 & 0.015 & 0.036 & 0.134 & 0.008 \\
\hline & $(0.073)$ & $(0.070)$ & $(0.061)$ & $(0.026)$ & $(0.028)$ & (0.024) \\
\hline \multirow[t]{2}{*}{ male } & 3.380 & 3.624 & 7.179 & -0.397 & -1.510 & 2.323 \\
\hline & $(0.860)$ & $(0.855)$ & $(1.814)$ & $(0.504)$ & $(0.507)$ & $(0.422)$ \\
\hline \multirow[t]{2}{*}{ age } & 0.389 & 0.448 & 0.176 & 0.290 & 0.327 & 0.355 \\
\hline & $(0.110)$ & $(0.112)$ & (0.129) & $(0.051)$ & $(0.062)$ & $(0.060)$ \\
\hline \multirow{2}{*}{$\begin{array}{l}\text { Number children in household } \\
1920\end{array}$} & -0.290 & -0.479 & -0.235 & -0.348 & -0.612 & -0.362 \\
\hline & $(0.200)$ & $(0.210)$ & $(0.305)$ & $(0.096)$ & $(0.116)$ & $(0.096)$ \\
\hline \multirow[t]{2}{*}{ Current region $=$ south } & -3.343 & -6.366 & -0.899 & -1.503 & -2.400 & -0.773 \\
\hline & (1.892) & (2.108) & (1.928) & $(1.052)$ & (1.315) & $(1.317)$ \\
\hline \multirow[t]{2}{*}{ Current region $=$ north } & 1.325 & 2.158 & 1.019 & 1.243 & 2.107 & 0.474 \\
\hline & $(2.438)$ & (2.162) & (2.206) & $(1.020)$ & (1.239) & (1.204) \\
\hline \multirow[t]{2}{*}{ Current region $=$ central } & & & & -1.995 & -2.669 & -0.898 \\
\hline & & & & $(1.018)$ & $(1.265)$ & $(1.228)$ \\
\hline \multirow[t]{2}{*}{ Constant } & -5.216 & 7.472 & 4.925 & 2.545 & 13.911 & 9.640 \\
\hline & (4.046) & $(3.435)$ & $(4.267)$ & $(1.715)$ & $(1.865)$ & $(1.962)$ \\
\hline Observations & 298 & 298 & 99 & 2167 & 2167 & 1371 \\
\hline R-squared & 0.45 & 0.34 & 0.34 & 0.36 & 0.13 & 0.17 \\
\hline
\end{tabular}

Standard errors are clustered at the family level. Families are in both the 1880 Census and 1920 IPUMs and merged based on data for the male head of household in 1920 (the "fathers" in the 1920 data). Match is on first name, last name, year of birth, race, place of birth, mother's place of birth, father's place of birth. Father's are ages 0-15 in 1880. 


\section{Appendix Table I \\ The Location of Black Households in New York Metro Area and New England in the $1880100 \%$ Sample}

\begin{tabular}{lr}
\hline New York, New York, New York & 1404 \\
Brooklyn, Kings, New York & 790 \\
Flushing, Queens, New York & 90 \\
Jamaica, Queens, New York & 56 \\
Oyster Bay, Queens, New York & 56 \\
North Hempstead, Queens, New York & 55 \\
Huntington, Suffolk, New York & 50 \\
Babylon, Suffolk, New York & 41 \\
Flatbush, Kings, New York & 31 \\
& \\
Providence, Providence, Rhode Island & 282 \\
Boston, Suffolk, Massachusetts & 265 \\
New Haven, New Haven, Connecticut & 262 \\
Hartford, Hartford, Connecticut & 178 \\
Cambridgeport, Cambridge, Middlesex, Ma & 83 \\
Worcester, Worcester, Massachusetts & 83 \\
Springfield, Hampden, Massachusetts & 82 \\
Newport, Newport, Rhode Island & 74 \\
New Bedford, Bristol, Massachusetts & 70 \\
Bridgeport, Fairfield, Connecticut & 58 \\
South Kingstown, Washington, Rhode Isla & 47 \\
Stonington, New London, Connecticut & 43 \\
Norwich, New London, Connecticut & 41 \\
Chelsea, Suffolk, Massachusetts & 40 \\
Norwalk, Fairfield, Connecticut & 39 \\
Pittsfield, Berkshire, Massachusetts & 35 \\
Greenwich, Fairfield, Connecticut & 32 \\
Danbury, Fairfield, Connecticut & 31 \\
Lynn, Essex, Massachusetts & 30 \\
Walpole, Norfolk, Massachusetts & 1 \\
Total Households in Above Location & 4349 \\
& \\
Total in Sample & 6777 \\
\hline
\end{tabular}

Notes: Data are from 100\% sample of 1880 Census data for New England and for New York Metro Area. 


\begin{tabular}{|c|c|c|c|c|c|}
\hline & Frequency & Percent & & Frequency & Percent \\
\hline $\mathrm{AL}$ & 6 & $0.07 \%$ & Africa & 9 & $0.10 \%$ \\
\hline AR & 1 & $0.01 \%$ & Bermuda & 1 & $0.01 \%$ \\
\hline CA & 1 & $0.01 \%$ & Brazil & 3 & $0.03 \%$ \\
\hline CT & 1389 & $15.84 \%$ & Canada & 92 & $1.05 \%$ \\
\hline DC & 151 & $1.72 \%$ & Cuba & 2 & $0.02 \%$ \\
\hline $\mathrm{DE}$ & 37 & $0.42 \%$ & England & 2 & $0.02 \%$ \\
\hline FL & 23 & $0.26 \%$ & France & 3 & $0.03 \%$ \\
\hline GA & 3 & $0.03 \%$ & Germany & 35 & $0.40 \%$ \\
\hline IA & 1 & $0.01 \%$ & Haiti & 2 & $0.02 \%$ \\
\hline IL & 4 & $0.05 \%$ & Ireland & 20 & $0.23 \%$ \\
\hline IN & 7 & $0.08 \%$ & Italy & 2 & $0.02 \%$ \\
\hline KS & 1 & $0.01 \%$ & Jamaica & 2 & $0.02 \%$ \\
\hline KY & 1 & $0.01 \%$ & Nova Scotia & 611 & $6.97 \%$ \\
\hline LA & 3 & $0.03 \%$ & Prussia & 2 & $0.02 \%$ \\
\hline MA & 962 & $10.97 \%$ & Spain & 41 & $0.47 \%$ \\
\hline MD & 21 & $0.24 \%$ & Turkey & 3 & $0.03 \%$ \\
\hline ME & 182 & $2.08 \%$ & & & \\
\hline MI & 155 & $1.77 \%$ & Illegible & 340 & $3.88 \%$ \\
\hline MO & 3 & $0.03 \%$ & & & \\
\hline MS & 1 & $0.01 \%$ & Total & 8770 & 100 \\
\hline $\mathrm{NC}$ & 3 & $0.03 \%$ & & & \\
\hline $\mathrm{NH}$ & 50 & $0.57 \%$ & & & \\
\hline NJ & 89 & $1.01 \%$ & & & \\
\hline NY & 3151 & $35.93 \%$ & & & \\
\hline $\mathrm{OH}$ & 3 & $0.03 \%$ & & & \\
\hline PA & 394 & $4.49 \%$ & & & \\
\hline RI & 2 & $0.02 \%$ & & & \\
\hline $\mathrm{SC}$ & 513 & $5.85 \%$ & & & \\
\hline $\mathrm{TN}$ & 7 & $0.08 \%$ & & & \\
\hline $\mathrm{TX}$ & 1 & $0.01 \%$ & & & \\
\hline VA & 2 & $0.02 \%$ & & & \\
\hline VT & 344 & $3.92 \%$ & & & \\
\hline WA & 62 & $0.71 \%$ & & & \\
\hline WI & 7 & $0.08 \%$ & & & \\
\hline WV & 12 & $0.14 \%$ & & & \\
\hline US & 8 & $0.09 \%$ & & & \\
\hline subtotal US & 7600 & $86.66 \%$ & & & \\
\hline
\end{tabular}

Notes: Data are from 100\% sample of 1880 Census data for New England and for New York Metro Area. (There are more female householders Table II than male householders in Table I and I have not yet fully solved this discrepancy.) 


\section{Appendix Table III}

\section{Occupations of Free Blacks Male Heads of Household \\ in NYC Metro Area and New England}

\section{Ten highest Occupational Income Scores and Ten most common}

\begin{tabular}{|c|c|c|c|}
\hline & Frequency & $\begin{array}{l}\text { Occupational } \\
\text { Income Score }\end{array}$ & $\begin{array}{r}\text { Manual } \\
(0-1)\end{array}$ \\
\hline Physicians and surgeons & 13 & 80 & 0 \\
\hline Dentists & 6 & 63 & 0 \\
\hline Lawyers and judges & 4 & 62 & 0 \\
\hline Locomotive engineers & 10 & 46 & 1 \\
\hline $\begin{array}{l}\text { Managers, officials, and proprietors, } \\
\text { n.e.c. }\end{array}$ & 2 & 42 & 0 \\
\hline Engineering & 18 & 41 & 0 \\
\hline Pharmacists & 3 & 40 & 0 \\
\hline Pressmen and plate printers--printing & 9 & 38 & 1 \\
\hline Brakemen--railroad & 10 & 36 & 1 \\
\hline Mail carriers & 1 & 34 & 0 \\
\hline Laborers, n.e.c. & 1,696 & 20 & 1 \\
\hline Farm laborers, wage workers & 687 & 9 & 1 \\
\hline Waiters and waitresses & 520 & 11 & 1 \\
\hline Barbers, beauticians, and manicurists & 336 & 19 & 1 \\
\hline Porters & 293 & 18 & 1 \\
\hline Private household workers, n.e.c. & 292 & 6 & 1 \\
\hline Farmers--owners and tenants & 270 & 14 & 1 \\
\hline Cooks, except private household & 198 & 16 & 1 \\
\hline Janitors and sextons & 126 & 19 & 1 \\
\hline Teamsters & 101 & 15 & 1 \\
\hline
\end{tabular}

Notes: Data are from 100\% Sample of 1880 Census. Data are for black male heads of household. Occupational income score is the median income for the occupation in 1950 and is expressed in hundreds of 1950 dollars per year. This variable was calculated by the Minnesota Population Center and the author mapped occupation titles in the $100 \%$ Census sample to the scores. 
Figure I

\section{Literacy Rates By Birth Cohort for Free Blacks and Slaves and Their Children And Grandchildren}

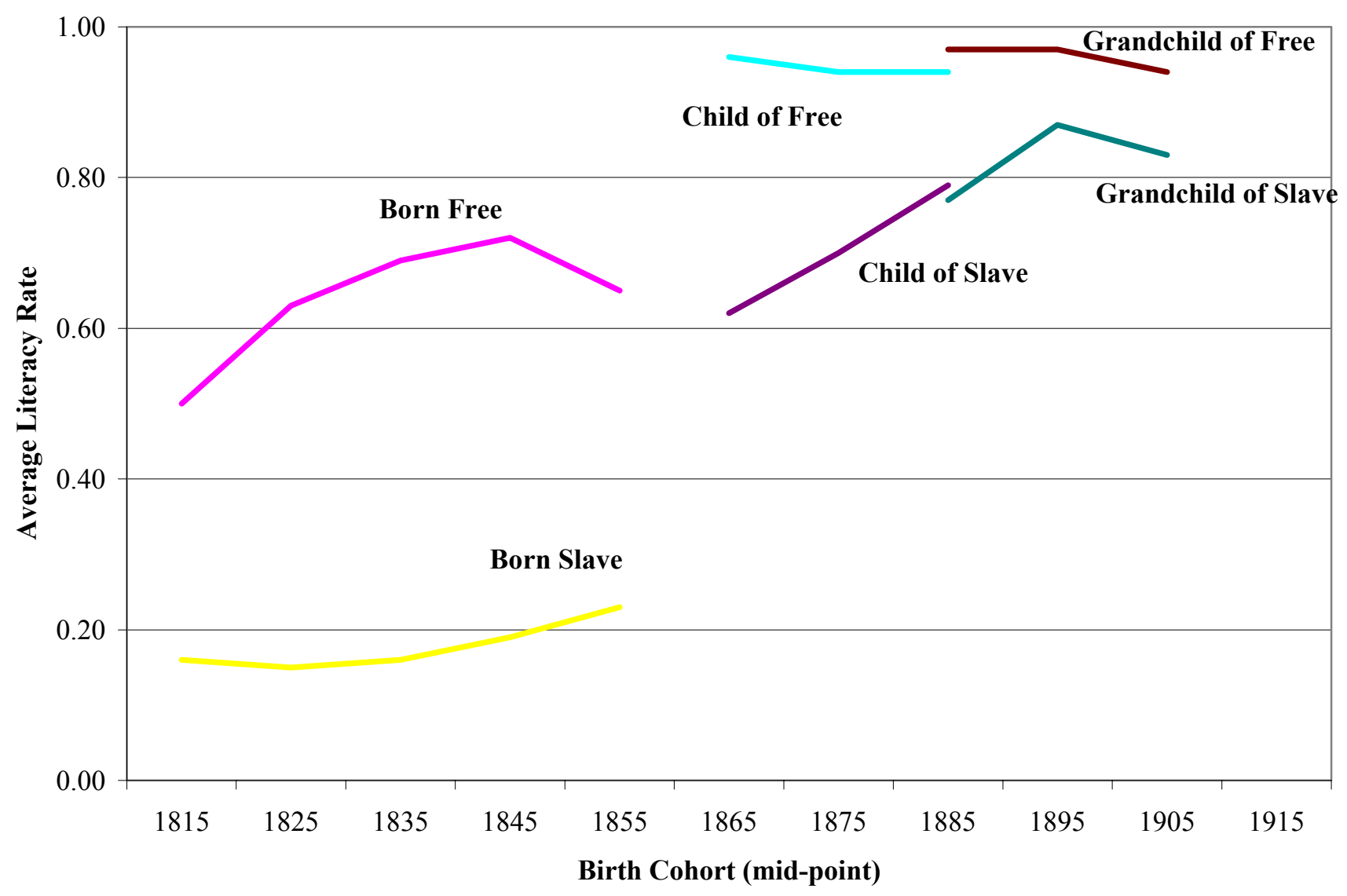

This figure is intended to show the literacy gap between free and slave blacks pre-1865 and how that gap eroded over time and across two generations. Means are taken by generation, by ten year cohort.

Notes: Data are from 1880 and 1920 Census IPUMS. Slavery status of self, mothers, and grandmothers is imputed from birth year and place of birth. Mother and mother's mother are used to assign slavery status of parents or grandparents.. Literacy rates in the first generation are calculated from the 1880 data and the next two generations are taken from the 1920 data. Data from cohorts from $1865+$ are taken from the 1920 Census. This switch partially explains the discrete jump shown in the graph. Literacy is measured for persons age 10 or older. 
Figure II

\section{Literacy Rates By Birth Cohort for Whites and Blacks \\ Born Inside and Outside of the South}

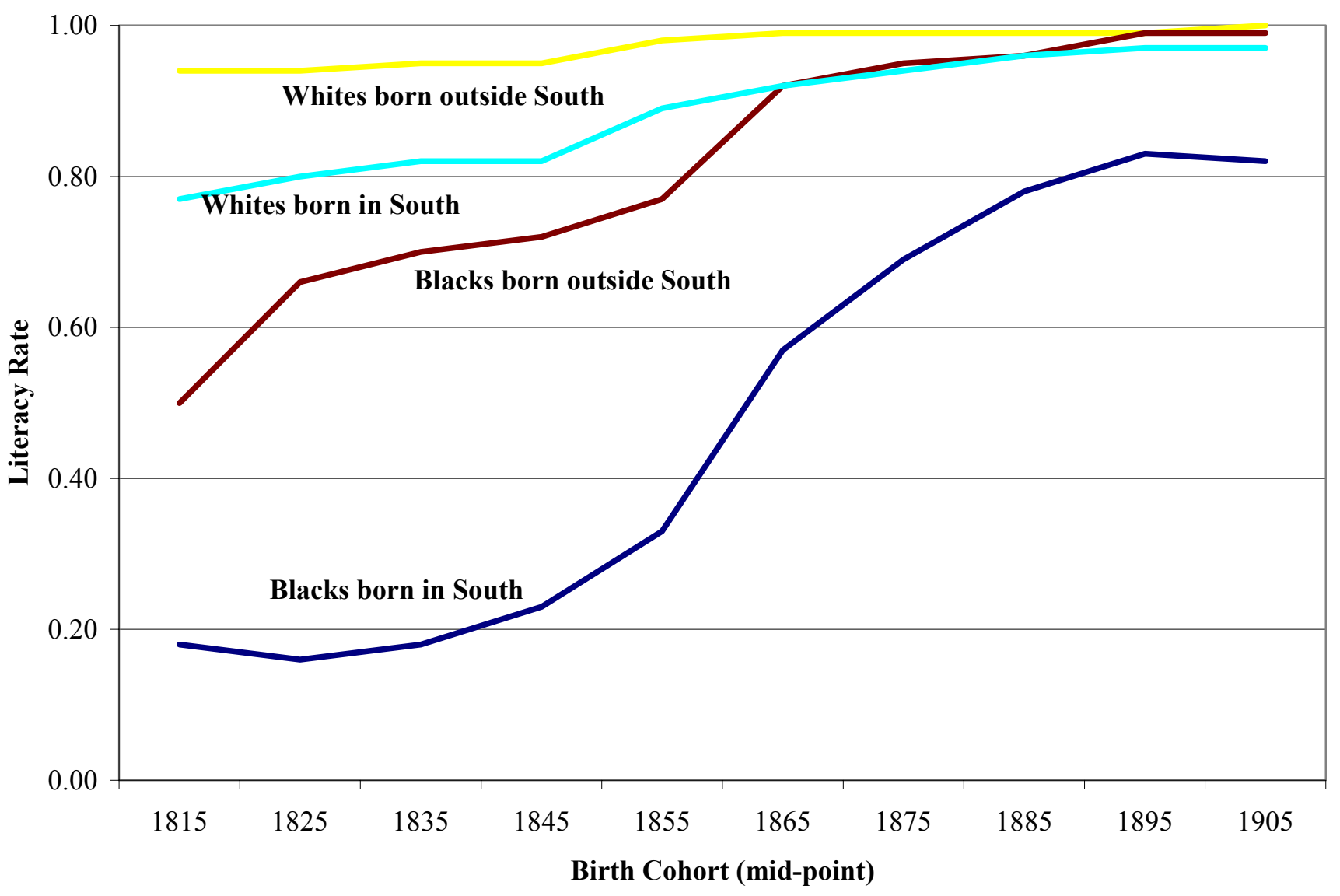

This figure shows average literacy by birth cohort, race, and region of birth (South and non-South). Means are taken by generation, by ten year cohort.

Notes: Data are from 1880 and 1920 Census IPUMS. Data from cohorts from $1865+$ are taken from the 1920 Census. This switch partially explains the discrete jump shown in the graph. Literacy is measured for persons age 10 or older. 
Figure III

Female Headed Household Rates By Birth Cohort for White and Black Children with

Grandmothers

Born Inside and Outside of South

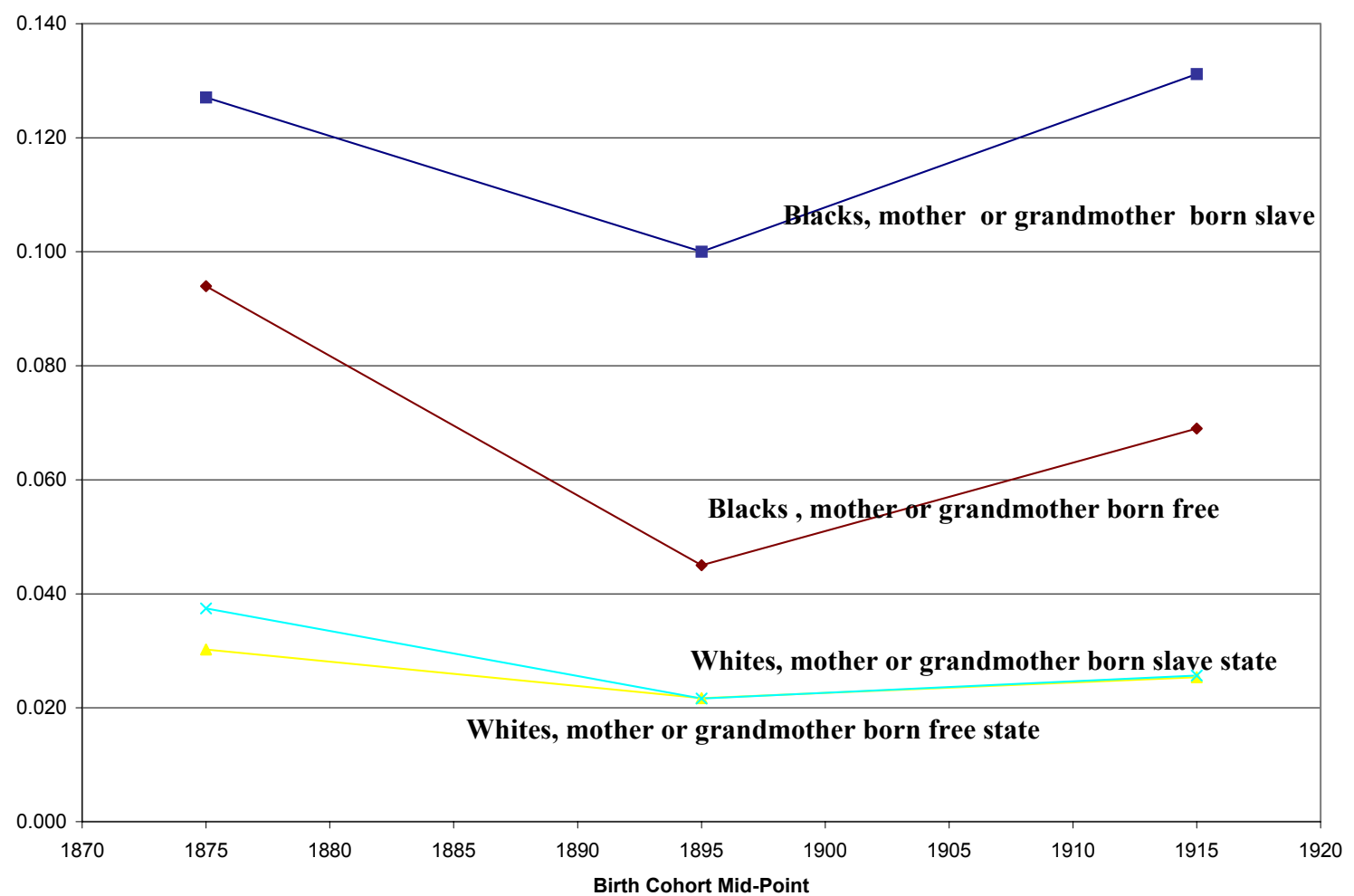

This figure measures whether children ages 0-10 are living in a female headed household. Data are from 1880, 1900, 1920 Census IPUMS. In 1880, data are stratified by race and mother born in slave state versus free. In 1900 and 1920, children are stratified by race and grandmother born in slave state versus free. In both 1900 and 1920, households are limited to those with mother born between 1865 and 1885, in order to increase the likelihood that the mother's mother was born before the end of the Civil War. This selection rule implies that I am selecting older mothers in 1920 and is a potential reason for the increase in female headed households shown in 1920. Female headed household is assumed when head of household is a woman (and her husband is not present in household). 
Figure IV

\section{Occupational Income Scores for Former Slaves and Free Blacks and Their Children and Grandchildren}

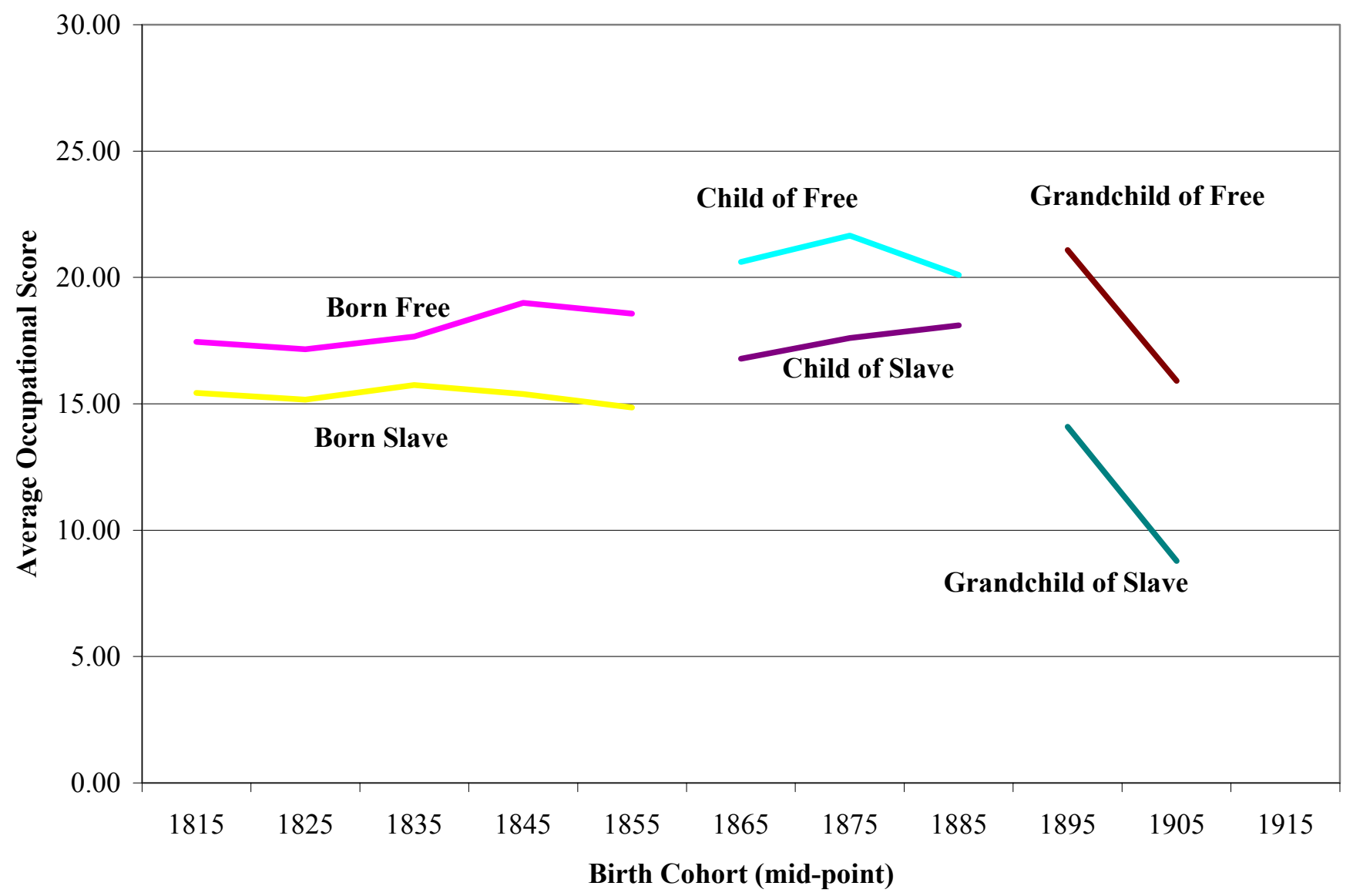

This figure shows average occupational income scores by birth cohort for free black men and former male slaves and their sons and grandsons. The occupational income score is calculated by IPUMS as the median annual income by occupation in 1950 and is reported in hundreds of 1950 dollars. Data for the later two generations come from the 1920 Census. The 1895 and 1905 cohorts have lower scores primarily because younger people are more likely to work in lower wage occupations. 
Figure V

\section{Occupational Scores for Whites and Blacks By Birth Cohort And Born in South}

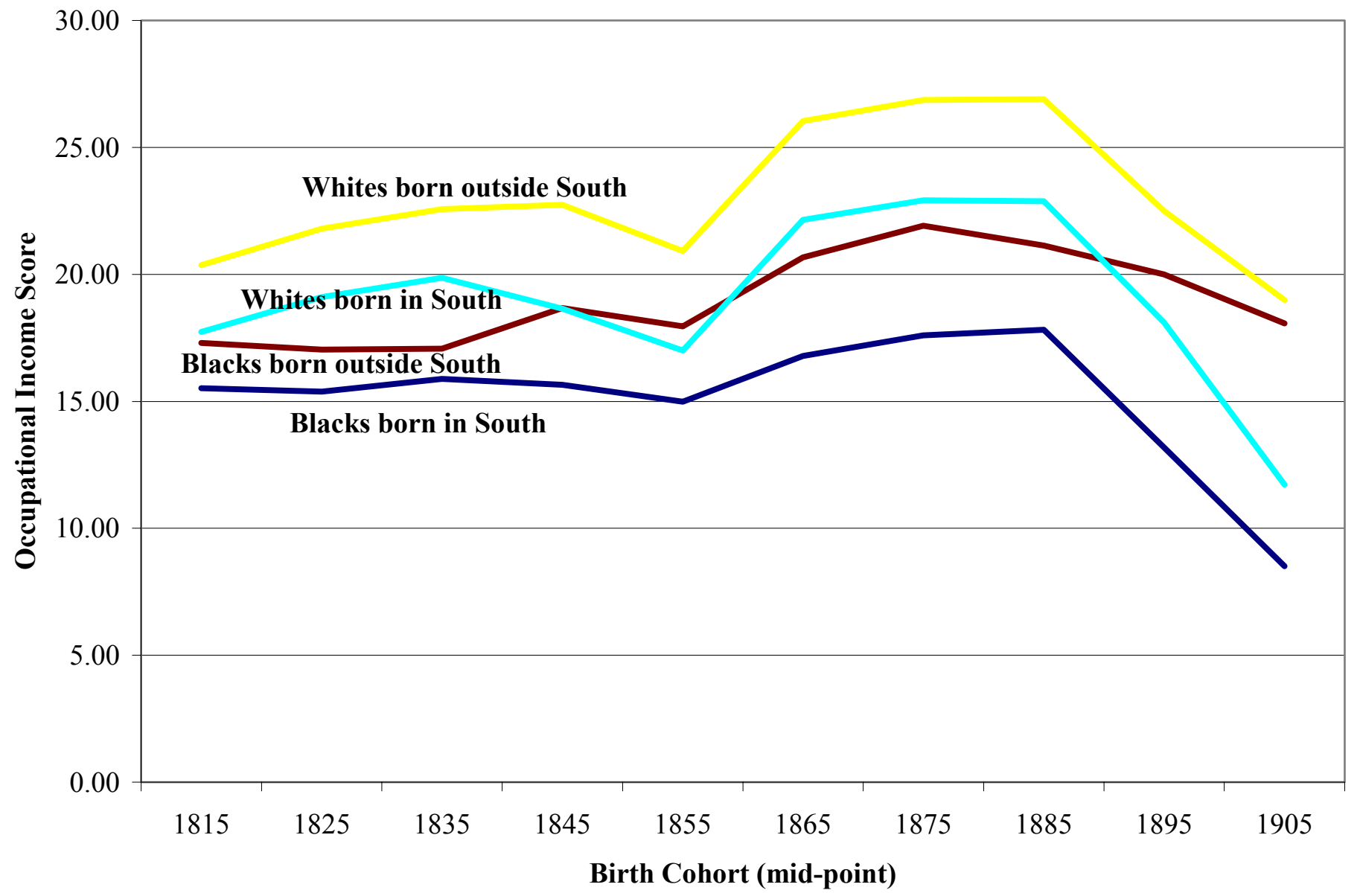

The figure shows average occupational score by birth cohort, race and born in South. The occupational income score is calculated by IPUMS as the median annual income by occupation in 1950 and is reported in hundreds of 1950 dollars. Data for the later two generations come from the 1920 Census. The 1895 and 1905 cohorts have lower scores primarily because younger people are more likely to work in lower wage occupations. 
Figure VI

\section{Transmission of Literacy From Parents to Children \\ By Cohort and Race}

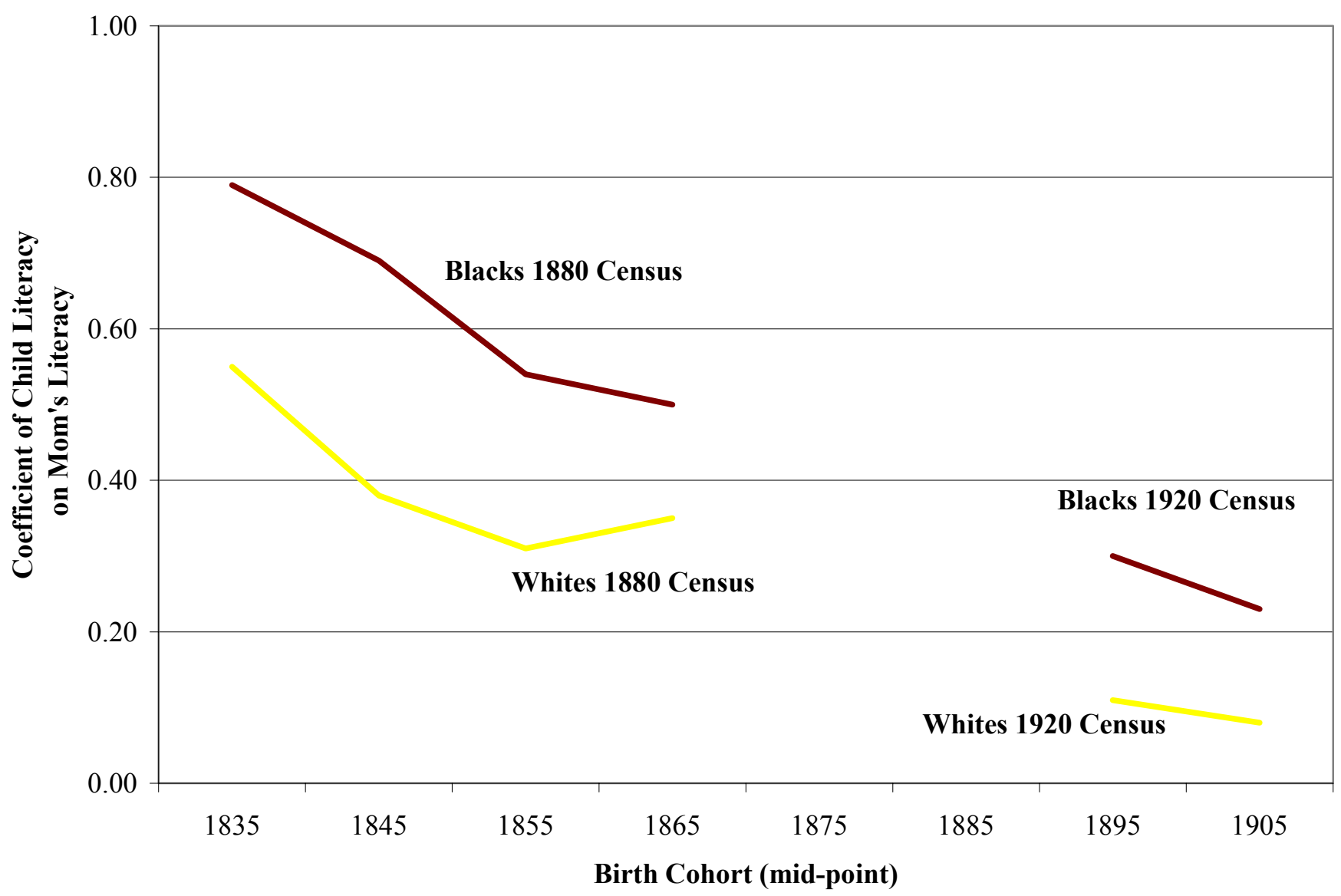

The transmission rate is defined as the child's literacy status (0-1) regressed on mother's literacy status (01) by cohort of child's birth. This is calculated for 1880 and 1920 households in which there were children of the householder present. 
Figure VII

Transmission of Occupational Income Score From Fathers to Sons

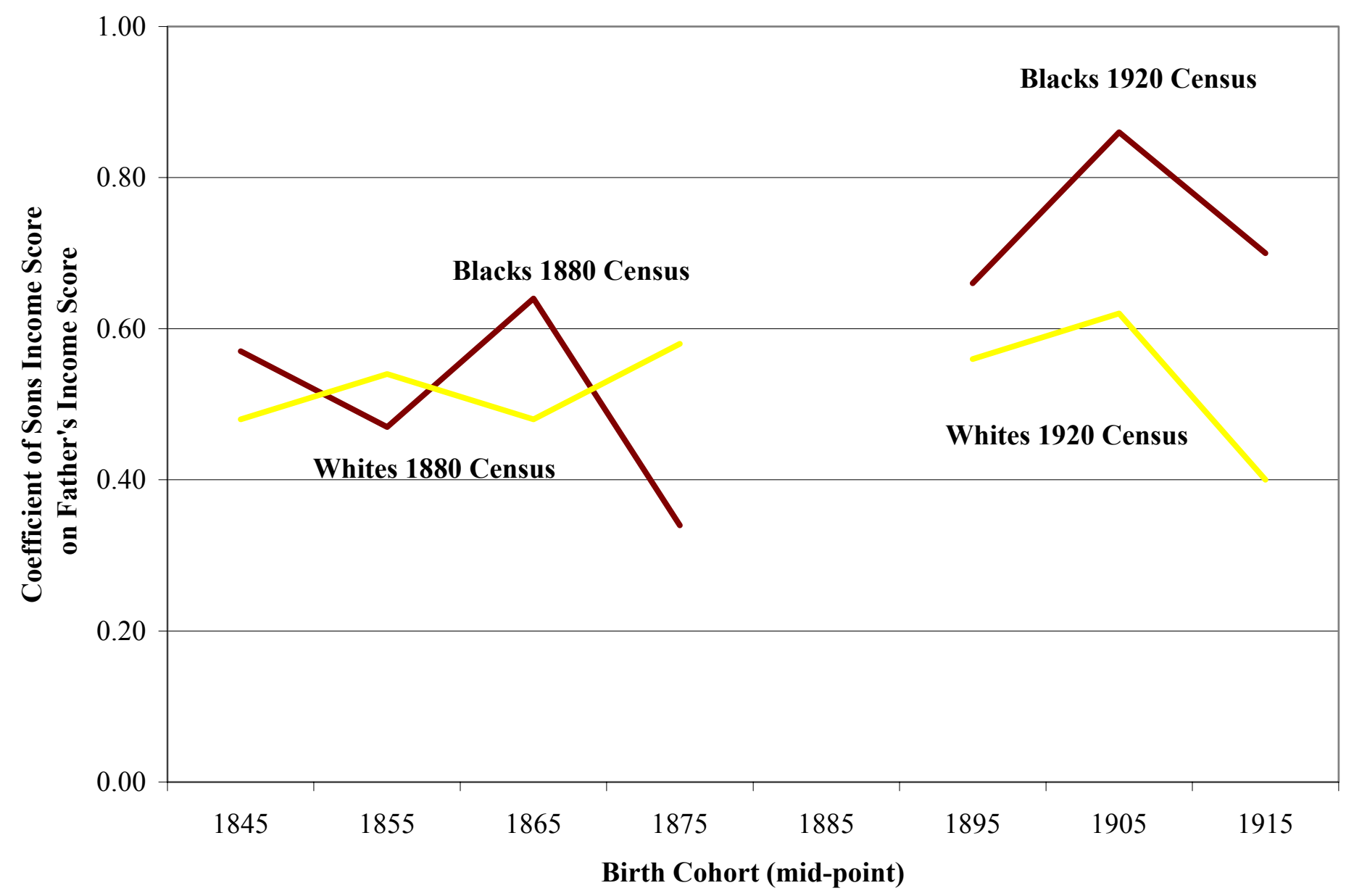

The transmission rate is the coefficient obtains from regressing son's occupational score on the father's occupational score. Data are from 1880 and 1920 IPUMS. Sample includes those households with sons of household head present. 


\section{Figure VIII}

\section{Probability of Living With One's Parents By Age and Race 1920 Census}

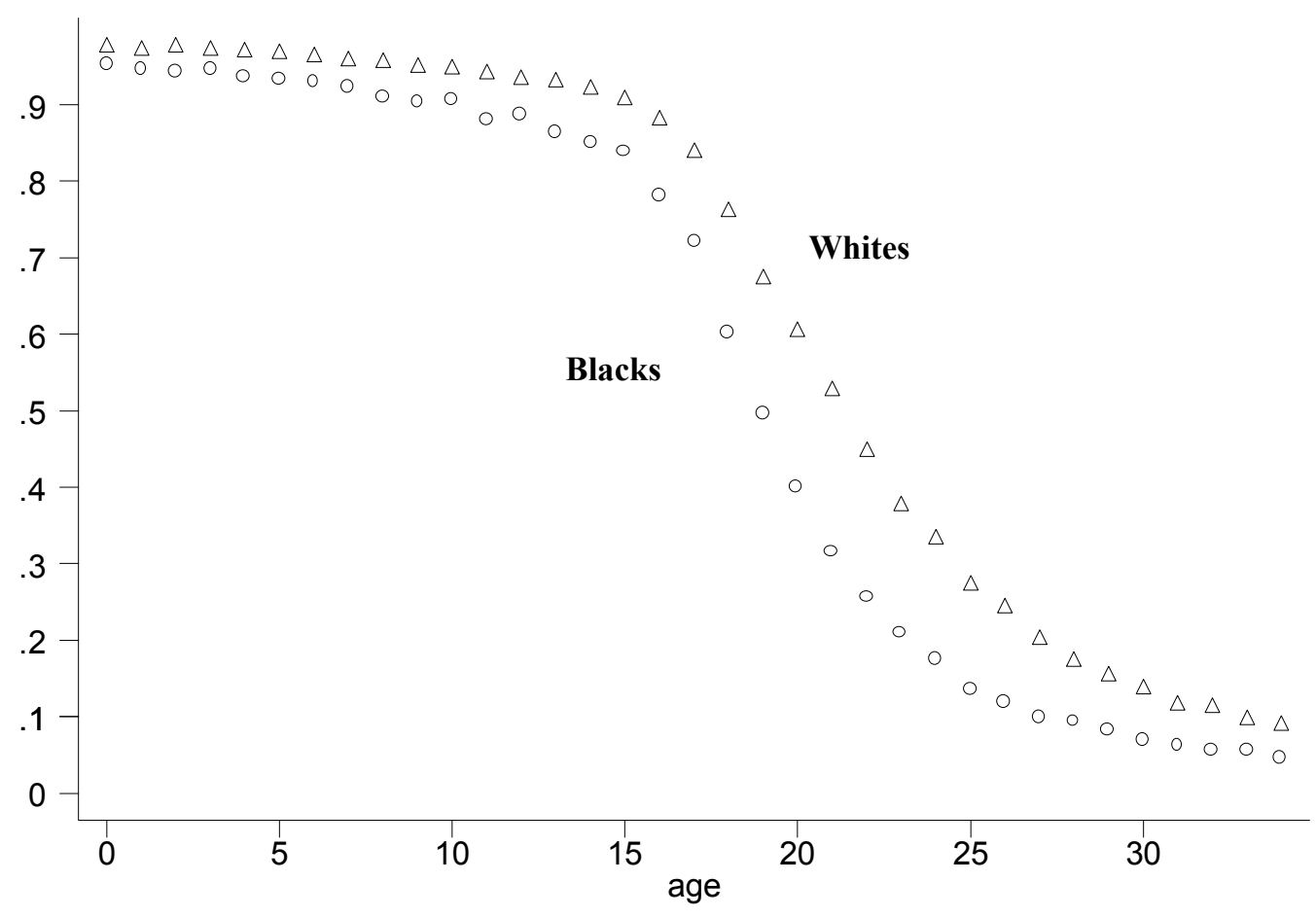

This show the fraction of children who live with one or both parents (and the parents are the householders). Data are from 1920 households. The transmission coefficients elsewhere in the paper are calculated for households with both parents and children. 
Figure IX

Distributions of Occupational Score in 1880 For Heads of Household

Black Heads of Household

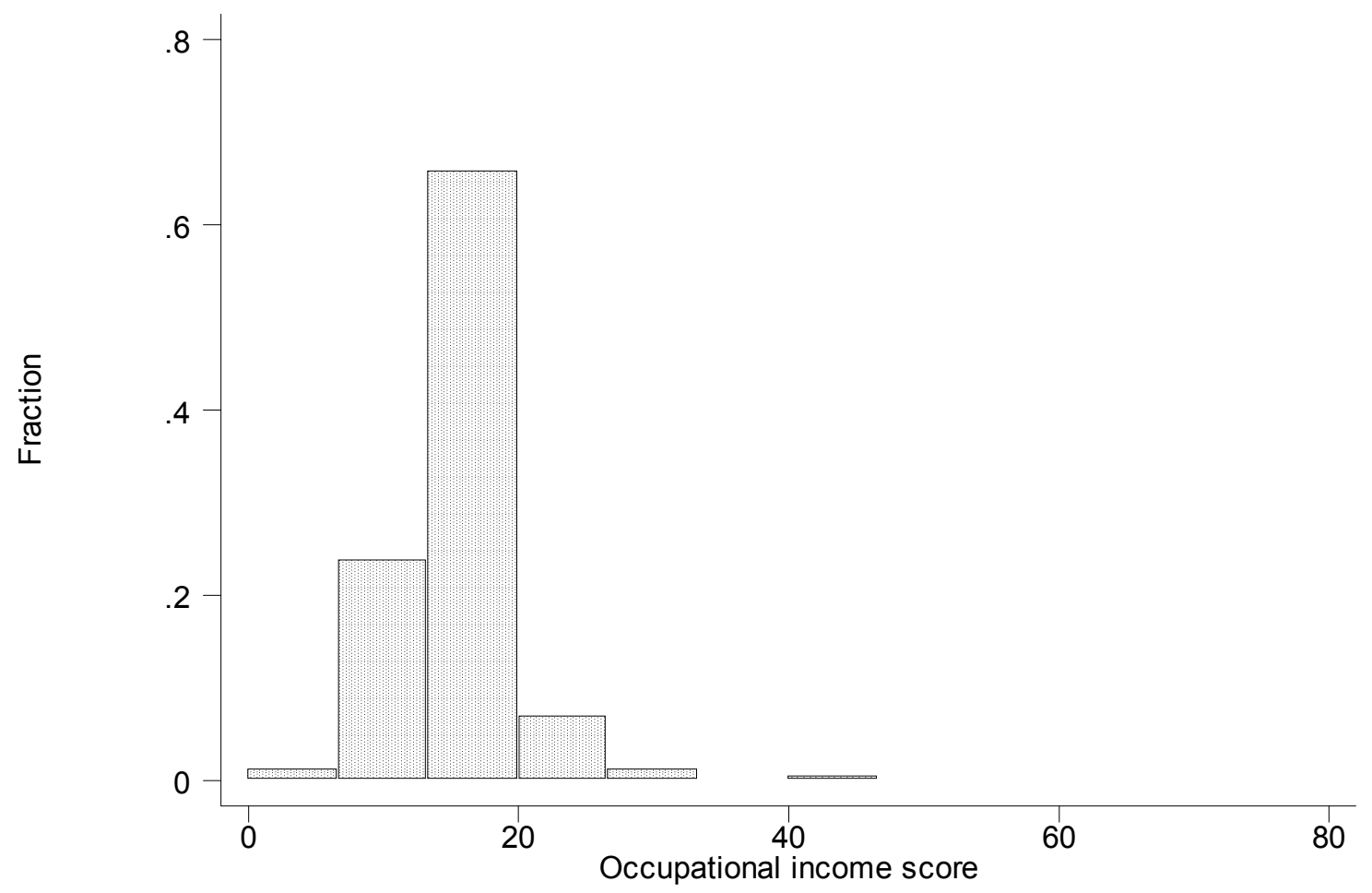

White Heads of Household

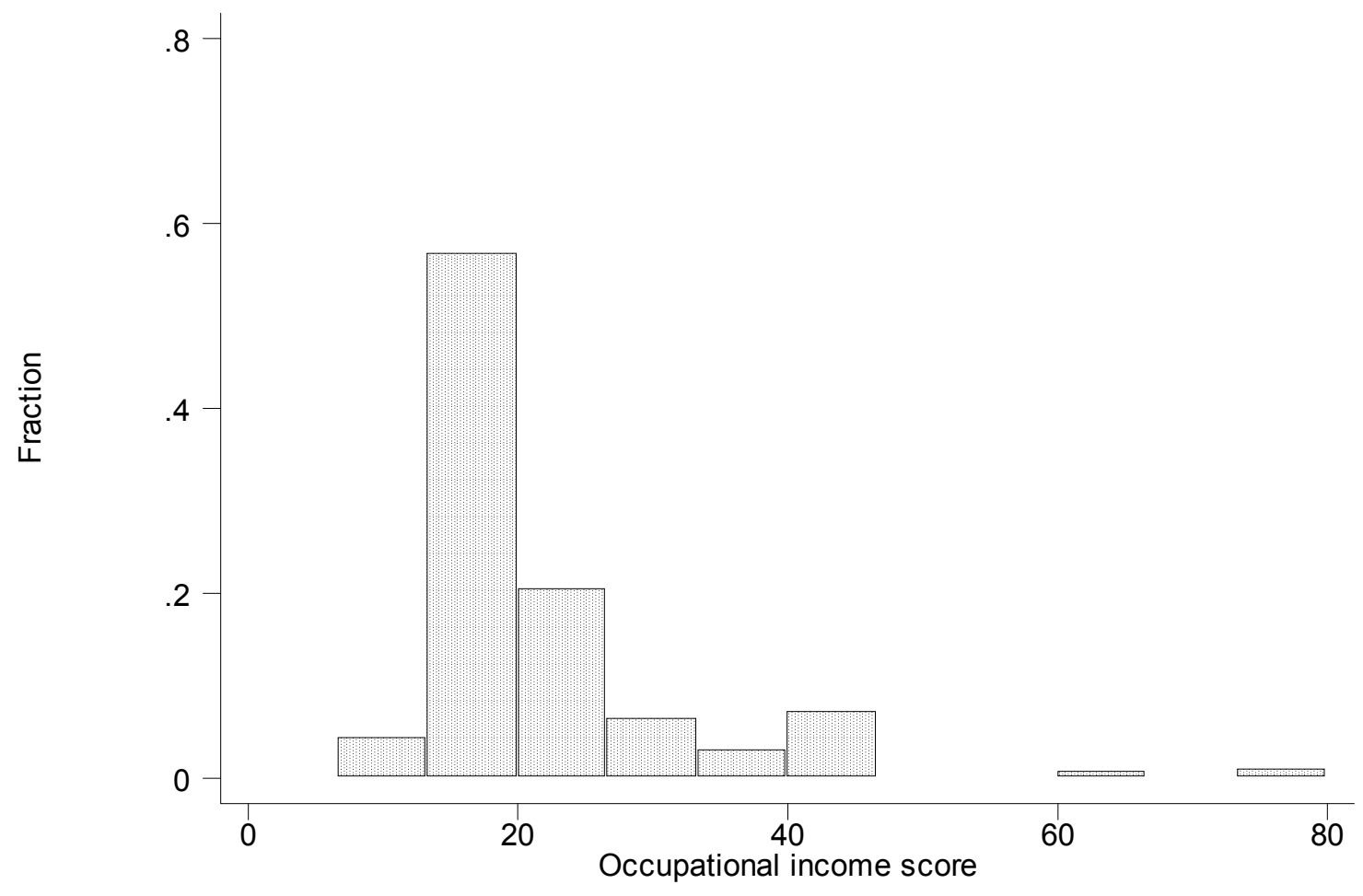


Figure $\mathrm{X}$

Distributions of Occupational Score in 1920 For Heads of Household

Occscore for black HH 1920

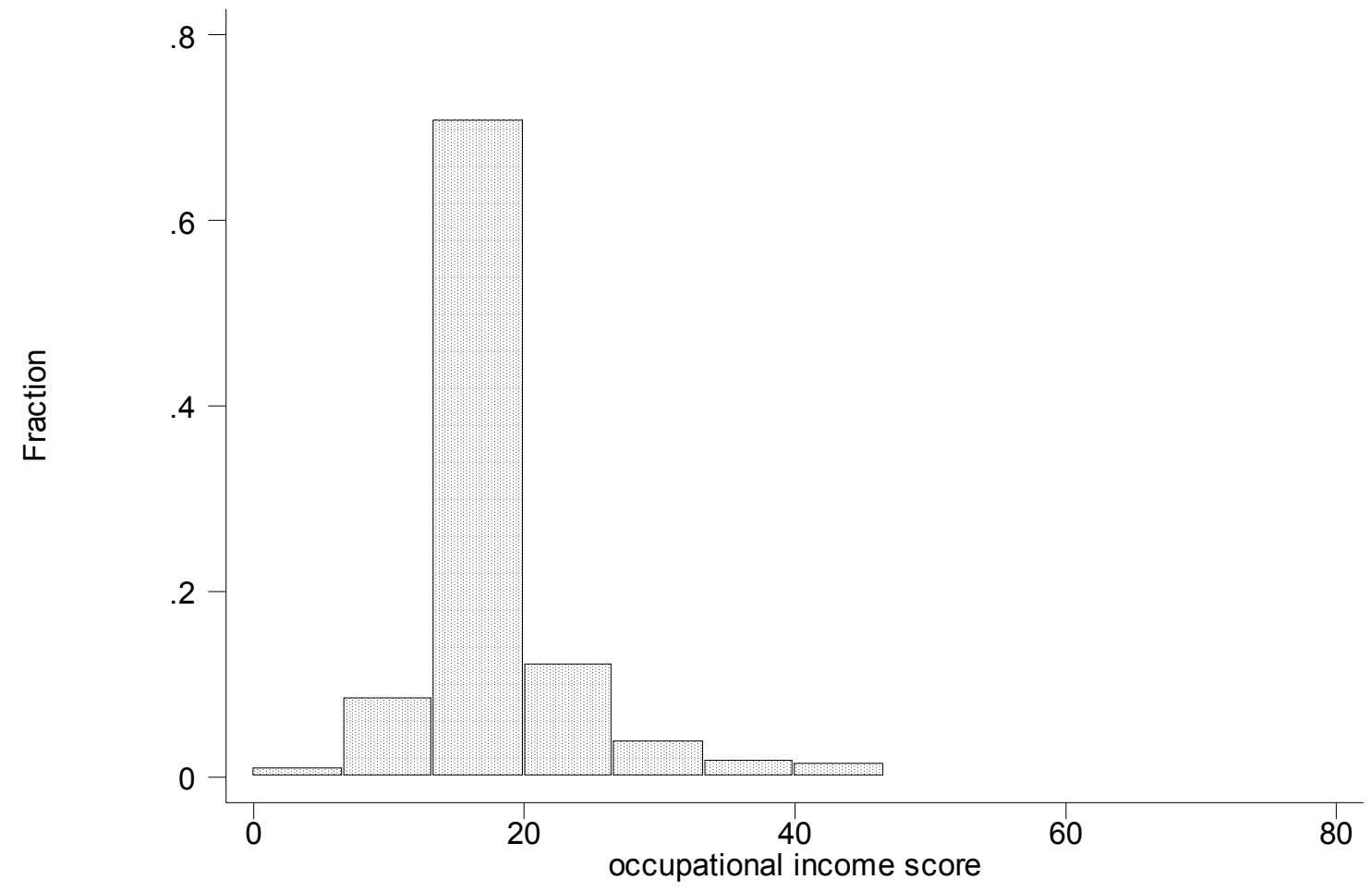

White HH

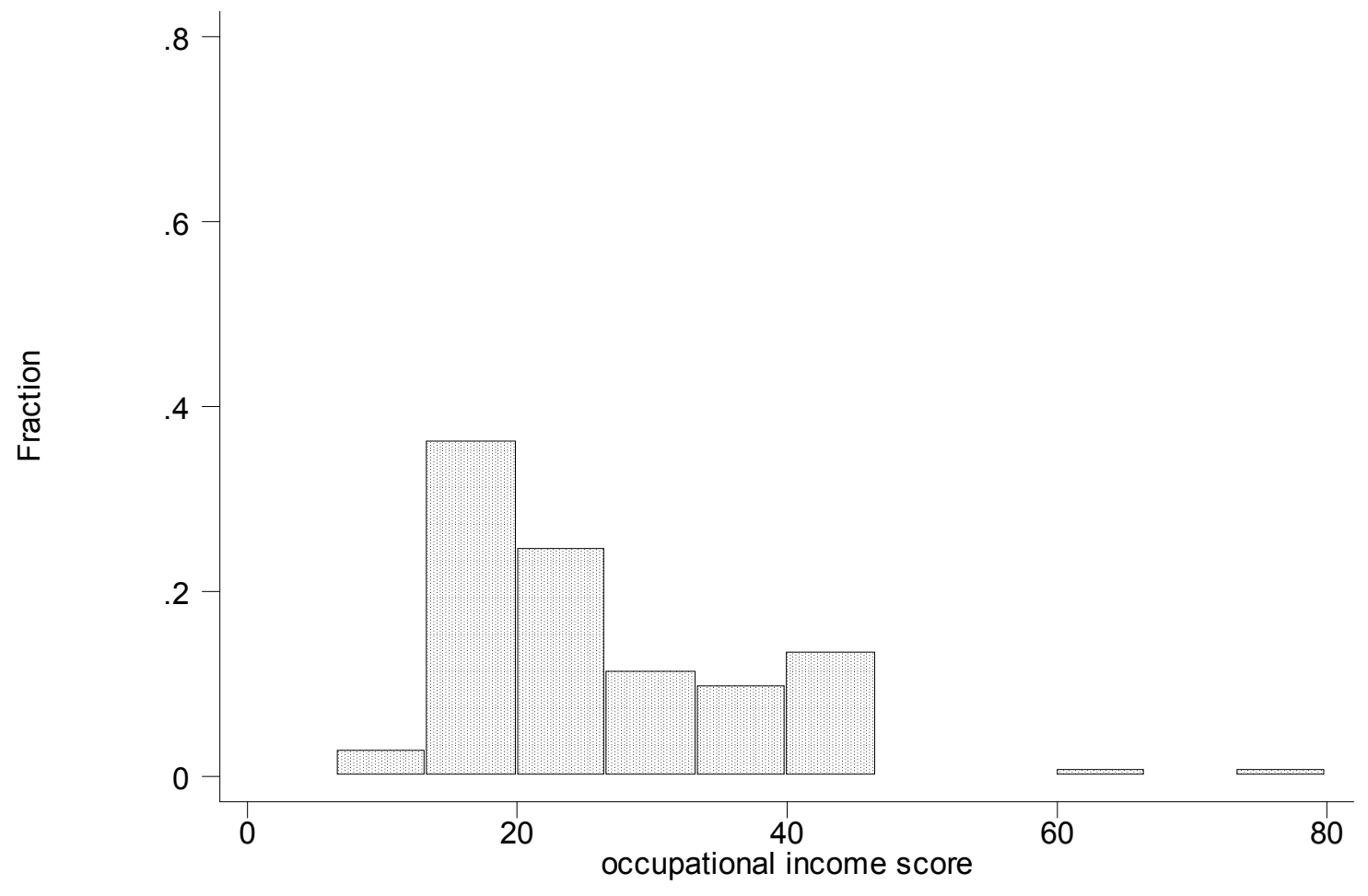

